\title{
Synthesis of earthworm trace metal uptake and bioaccumulation data: role of soil concentration, earthworm ecophysiology, and experimental design
}

Article

Accepted Version

Creative Commons: Attribution-Noncommercial-No Derivative Works 4.0

Richardson, J. B., Görres, J. H. and Sizmur, T. (2020)

Synthesis of earthworm trace metal uptake and

bioaccumulation data: role of soil concentration, earthworm ecophysiology, and experimental design. Environmental Pollution, 262. 114126. ISSN 0269-7491 doi: https://doi.org/10.1016/j.envpol.2020.114126 Available at https://centaur.reading.ac.uk/89384/

It is advisable to refer to the publisher's version if you intend to cite from the work. See Guidance on citing.

Published version at: https://www.sciencedirect.com/science/article/pii/S0269749119360130

To link to this article DOI: http://dx.doi.org/10.1016/j.envpol.2020.114126

Publisher: Elsevier

All outputs in CentAUR are protected by Intellectual Property Rights law, including copyright law. Copyright and IPR is retained by the creators or other copyright holders. Terms and conditions for use of this material are defined in the End User Agreement. 


\section{www.reading.ac.uk/centaur}

\section{CentAUR}

Central Archive at the University of Reading

Reading's research outputs online 
1 Synthesis of earthworm trace metal uptake and bioaccumulation data: role of soil concentration, earthworm ecophysiology, and experimental design

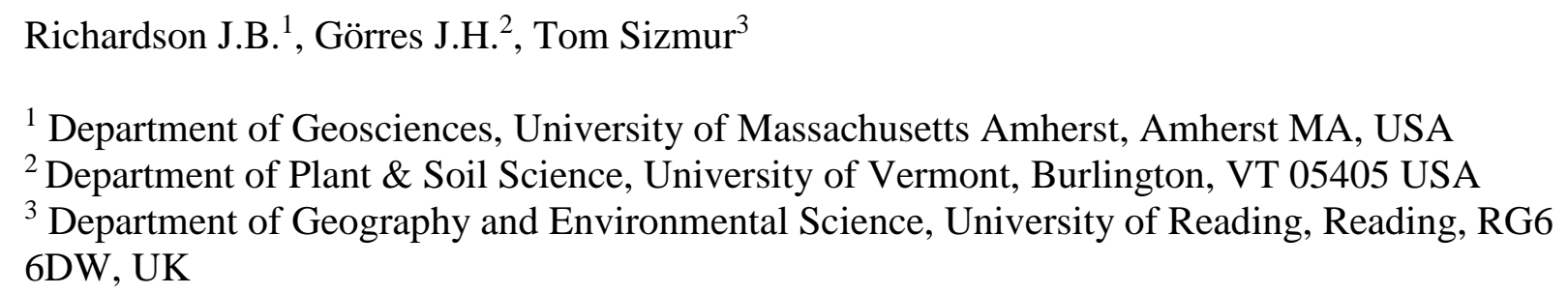

*Corresponding Author

Justin Richardson

University of Massachusetts Amherst

233 Morrill Science Center

Amherst MA 01003

Phone: 413-545-4840 


\section{Abstract}

Trace metals can be essential for organo-metallic structures and oxidation-reduction in

27 metabolic processes or may cause acute or chronic toxicity at elevated concentrations. The

28 uptake of trace metals by earthworms can cause transfer from immobilized pools in the soil to

29 predators within terrestrial food chains. We report a synthesis and evaluation of uptake and bioaccumulation empirical data across different metals, earthworm genera, ecophysiological

31 groups, soil properties, and experimental conditions (metal source, uptake duration, soil

32 extraction method). Peer-reviewed datasets were extracted from manuscripts published before

33 June 2019. The 56 studies contained 3513 soil-earthworm trace metal concentration paired data

34 sets across 11 trace metals ( $\mathrm{As}, \mathrm{Cd}, \mathrm{Cr}, \mathrm{Cu}, \mathrm{Hg}, \mathrm{Mn}, \mathrm{Ni}, \mathrm{Pb}, \mathrm{Sb}, \mathrm{U}, \mathrm{Zn}$ ). Across all field and

35 laboratory experiments studied, the median concentrations of $\mathrm{Hg}, \mathrm{Pb}$, and $\mathrm{Cd}$ in earthworm

36 tissues that were above concentrations known to be hazardous for consumption by small

37 mammals and avian predators but not for $\mathrm{Cu}, \mathrm{Zn}, \mathrm{Cr}, \mathrm{Ni}$, and As. Power regressions show only

$38 \mathrm{Hg}$ and $\mathrm{Cd}$ earthworm tissue concentrations were well-correlated with soil concentrations with

$39 \mathrm{R}^{2}>0.25$. However, generalized linear mixed-effect models reveal that earthworm

40 concentrations were significantly correlated with soil concentrations for log-transformed $\mathrm{Hg}, \mathrm{Cd}$,

$41 \mathrm{Cu}, \mathrm{Zn}, \mathrm{As}, \mathrm{Sb}(\mathrm{p}<0.05)$. Factors that significantly contributed to these relationships included

42 earthworm genera, ecophysiological group, soil $\mathrm{pH}$, and organic matter content. Moreover,

43 spiking soils with metal salts, shortening the duration of exposure, and measuring exchangeable

44 soil concentrations resulted in significantly higher trace metal uptake or greater bioaccumulation

45 factors. Our results highlight earthworms are able to consistently bioaccumulate toxic metals ( $\mathrm{Hg}$

46 and Cd only) across field and laboratory conditions. However, future experiments should

47 incorporate greater suites of trace metals, broader genera of earthworms, and more diverse 
48 laboratory and field settings generate data to devise universal quantitative relationships between

49 soil and earthworm tissue concentrations. 
Keywords

51 Bioconcentration; soil pollution; toxic metals; heavy metals; environmental toxicology

52

\section{Capsule}

54 The meta-analysis revealed that while concentrations affected earthworm $\mathrm{Cd}$ and $\mathrm{Hg}$

55 concentrations, earthworm properties, soil properties, and experimental design, source of metal, 56 and exposure duration significantly affected trace metal uptake.

57

58

59

60

61 at abundances $<0.1 \%$ of the Earth's crust (Adriano, 2001). Some trace metals, such as chromium

$62(\mathrm{Cr})$, copper $(\mathrm{Cu})$, zinc $(\mathrm{Zn})$, manganese $(\mathrm{Mn})$, and nickel $(\mathrm{Ni})$ are essential for organisms due to

63 their roles in folding of organo-metallic structures such as enzymes and proteins and regulating 64 oxidation-reduction in metabolic processes (Hooda, 2010). Other trace metals, such as arsenic $65(\mathrm{As})$, cadmium $(\mathrm{Cd})$, mercury $(\mathrm{Hg})$, lead $(\mathrm{Pb})$, antimony $(\mathrm{Sb})$, and uranium $(\mathrm{U})$ are non-essential 66 and can cause acute or chronic toxicity when accumulated even in small quantities by plants and 67 animals (Adriano, 2001; Kabata-Pendias, 2010). Trace metals are naturally present in the terrestrial environments at low concentrations but may occur at higher concentrations due to 69 lithology (Peng et al., 2004; Maleri et al., 2008; Tijani et al., 2006) but more frequently from 70 local and regional pollution from smelters (Morgan and Morgan, 1990; Filzek etal 2004; Dai et 71 al., 2004; Nannoni et al., 2011), roads (Pagotto et al 2001), agricultural soil amendments 
72 (Centofanti et al 2016), mining activities (Wang et al., 2009; Duarte et al., 2014). Urban areas

73 with non-point source pollution can also be substantially contaminated with trace metals.

Earthworms are one of the most important soil fauna due to their size and biomass

75 compared to other soil fauna, and their ability to physically, biologically and chemically alter soils (Scheu 1987; Bohlen et al., 2004; Sizmur and Hodson, 2009; Sizmur et al 2011). The

77 uptake of trace metals by earthworms is of importance not only because of the potential toxicity

78 to the earthworms themselves, but also for trophic transfer of metals from soils to predators and

79 detritovores in terrestrial food webs (e.g. Talmage and Walton, 1993; Nahmani et al 2007;

80 Richardson et al 2016). It is generally agreed earthworms can take up metals through ingestion of

81 soils and dermally by exposure to dissolved metals in soil pore water (Vijver et al., 2003).

82 Spurgeon and Hopkins (1999) showed that while earthworms were capable of regulating their

83 internal tissue concentrations of essential metals, such as $\mathrm{Cu}$ and $\mathrm{Zn}$, at an equilibrium level, the

84 tissue concentrations of non-essential metals, such as $\mathrm{Pb}$ and $\mathrm{Cd}$, do not reach equilibrium since

85 earthworms lack specific excretion mechanisms for these elements. Regulation of tissue

86 concentrations is also dependent on earthworm-specific physiological processes, such as the

87 excretion of metals by the calciferous glands or retention of metals within chloragogenous

88 tissues, where $\mathrm{Zn}$ and $\mathrm{Pb}$ are associated with 'Type $\mathrm{A}$ ' phosphate-rich insoluble granules and $\mathrm{Cu}$,

$89 \mathrm{Cd}$ and $\mathrm{Hg}$ are associated with 'Type B' sulfur-rich metallothionein-like proteins (Fischer and

90 Molnar 1993; Spurgeon and Hopkin 1999; Fraser et al., 2011; Karaca et al., 2010).

From the large number of studies on the bioaccumulation of trace metals by earthworms,

92 their tissue concentrations are considered a reliable indicator of trace metal bioavailability in

93 soils (Ma 1987; Suthar et al., 2008; Pérès et al., 2011). Linear and logarithmic equations have

94 been developed and analyzed in aggregate to estimate uptake of metal by earthworms by 
95 Neuhauser et al., (1995), Sample et al., (1999), and Nahmani et al., (2007). As stated by

96 Nahmani et al., (2007) "Much work has been carried out on accumulation of metals by

97 earthworms in soils... Yet it is still not possible to predict with a high degree of confidence the

98 body burden of an earthworm..." The limitations to our capability to interpret and extrapolate

99 results from studies is due to the wide range of experimental conditions, with discrepancies

100 between laboratory conditions and the 'real world' environment. The literature contains many

101 studies that have focused on Lumbricidae earthworms under laboratory conditions. Moreover,

102 there are contradictions in soil to earthworm trace metal relationships reported. For example, soil

103 concentrations of $\mathrm{Cu}, \mathrm{Zn}$, or $\mathrm{Pb}$ were significantly correlated with earthworm tissue

104 concentrations $\left(\mathrm{R}^{2}>0.50\right)$ in some studies (e.g. Neuhauser, 1995; Sample et al., 1999; Ma 2004;

105 Alvarenga et al., 2013) while others reported no significant correlation and low explanatory

106 power $\left(\mathrm{R}^{2}<0.25\right)$ (e.g. Nahmani et al., 2007; Wang et al., 2012; Richardson et al., 2015;

107 González-Alcaraz et al., 2018). Thus, there is a need to undertake a synthesis of literature data

108 sets to further identify additional experimental design, soil, and earthworm properties hindering

109 universal relationship equations with strong predictive power.

110 Despite a vast body of literature, there remain a number of unanswered questions about

111 how soil properties (i.e. metal concentration, $\mathrm{pH}$, organic matter) influence the bioaccumulation

112 of metals by earthworms (Dai et al., 2004; Ma 2004; Karaca et al., 2010) and a universal

113 quantitative relationship between soil trace metal concentrations and earthworm tissue

114 concentrations is lacking. As a prime example, measuring bioaccumulation may be problematic

115 because the straightforward calculation of bioaccumulation factor (BAF; synonymous with

116 bioconcentration factor), involving the ratio of dry weight tissue concentrations by soil

117 concentrations, can be affected by the method used to measure soil concentrations. Furthermore, 
118 experimental design artefacts or generalizations may result from the conditions under which 119 trace metal bioaccumulation studies have been conducted. Bioaccumulation has been well120 studied for a limited set of trace metals $(\mathrm{Pb}, \mathrm{Cu}, \mathrm{Zn}, \mathrm{Cd})$ but similar relationships may not hold 121 true for many other trace metals. Experiments have been undertaken using a wide range of soil 122 types, ranging from very organic rich soils to support E. fetida (e.g. Suthar and Singh 2009 123 utilized a soil composed of up to $80 \%$ cow dung) or artificial soils, such as the OECD standard 124 soil, with $<10 \%$ organic matter (Nahmani et al., 2007). Soils are frequently spiked in the 125 laboratory with metal salts (Nahmani et al., 2007), which may not adequately represent trace 126 metal concentrations associated with organic matter and secondary oxides of field-contaminated 127 soils. Lastly, the duration of exposure adopted in laboratory bioassays can be far shorter than at 128 the time expected for attenuation to occur (Sheppard et al., 1997; Nahmani et al., 2007). The purpose of this study is to synthesise data on trace metal uptake and bioaccumulation 130 by earthworms, similar to previous meta-analyses but include additional experimental design 131 variables to evaluate broader patterns. This meta-analysis set out to revisit the soil-earthworm 132 uptake paradigm in our first question and explore three additional questions centered on soil133 earthworm properties and experimental design aspects. (1) To what extent are trace metals taken 134 up and bioaccumulated by earthworms across a broad range of earthworm genera ? (2) Does soil $135 \mathrm{pH}$, soil organic matter, genera and earthworm ecophysiological groups influence earthworm 136 uptake and bioaccumulation of all trace metals, or only specific metals? (3) Do experimental 137 design variables (e.g. source of metals, exposure duration) artificially influence the 138 bioaccumulation of trace metals in earthworms? (4) Which soil extraction methods are most 139 appropriate for quantifying bioaccumulation of trace metals by earthworms? The answers to 140 these four questions are needed to coalesce conflicting findings of earthworm metal 
141 bioaccumulation to move towards the generation of universally applicable relationships between 142 soil and earthworm trace metal concentrations.

Our meta-analysis utilized the rich-body of ISI-Web of Science listed literature

147 concerning trace metals in soils and their uptake by earthworms, ranging from laboratory

148 conditions to field experiments. The literature search of peer-reviewed publications published

149 before June 2019 reporting results on bioaccumulation of trace metals by earthworms was

150 performed using the ISI-Web of Science research database (e.g. Van Groenigen et al., 2014, 151 2019). We used the following search term:

155 The search yielded 267 studies that contained the desired search terms in their titles, 156 abstracts, keywords, and KeyWords Plus, which are words and phrases frequently used in the 157 references of an article. Studies not written in English were not included in these results. $158 \quad 2.2$ Study selection

160 the query search results. Studies that included an experimental treatment that may influence

161 bioaccumulation rate such as soil sterilization, fungi or bacterial amendments, addition of

162 pesticides were not included. Studies that focused on non-mineral soil media were not included

163 such as sewage sludges, organic horizons, and subaqueous soils. Soils that utilized metal 
treatments, such as sludges, metal salts, or contaminated soils from other areas were included in our study. A total of 119 full-texts were acquired for further inspection. Studies that were unable to be used in our study had one or more of the following issues: failure to report data in accessible format (e.g. data across treatments or sampling sites were not reported, or only reporting aggregate data), missing data set (e.g. soil concentrations not reported), failing to mention depuration of earthworms, not reporting concentrations as dry weight. Authors of recent studies (after 2005) focusing on several trace metals were contacted for data sets but all requests were unsuccessful. We excluded 63 studies of the 119 full texts screened and only 56 studies (Supplemental Table 1) met our criteria for use in our meta-analysis. All data are available in supplementary material. Field studies included in our meta-analysis included different ecosystems (forests, grasslands, agroecosystems), several climatic biomes (temperate, continental, tropical and subtropical), and multiple types of experimental designs (indoor and outdoor pot experiments, field plots of contaminated, uncontaminated, urban and preserved ecosystems).

\subsection{Data collection and extraction}

Important study metadata were collected (Year Published, First Author Last Name, Metal source as described in the study), earthworm information (Earthworm family, genera, species), experimental design (uptake duration, extraction method and instrumental used for trace metal analysis, treatments or site name, and number of replicates) and chemical data (\%SOM, pH, As, $\mathrm{Cd}, \mathrm{Cr}, \mathrm{Cu}, \mathrm{Hg}, \mathrm{Mn}, \mathrm{Ni}, \mathrm{Pb}, \mathrm{Sb}, \mathrm{U}, \mathrm{Zn}$ soil and earthworm tissue concentrations). Data were extracted from the 56 studies by transcription when presented in tables while data represented graphically was extracted manually using PlotDigitizer Version 2.6.6, released April 27 $7^{\text {th }}, 2014$ 
187 (http://plotdigitizer.sourceforge.net). The 56 studies contained 951 soil-earthworm trace metal 188 concentration paired data sets, with 3513 data points across 11 trace metals (As, $\mathrm{Cd}, \mathrm{Cr}, \mathrm{Cu}, \mathrm{Hg}$, $189 \mathrm{Mn}, \mathrm{Ni}, \mathrm{Pb}, \mathrm{Sb}, \mathrm{U}, \mathrm{Zn})$.

2.4 Statistical Analyses

Descriptive statistics were calculated using MATLAB (Mathworks, Natick, MA, USA)

193 For the figures and in text data, average values are given \pm 1 standard error of the mean. BAF

194 were calculated as the ratio of earthworm to soil trace metal concentrations using values obtained

195 from each study without log-transformation. Descriptive statistics for the pooled soil, earthworm,

196 and BAFs are given in Table 1. Power regressions, also commonly referred to as log-linear

197 regressions, were used to quantify the relationship between soil concentrations and earthworm

198 tissue concentrations in MATLAB. Linear regressions were not used because of their sensitivity

199 to higher concentration values over lower concentration values. Soil concentrations, earthworm

200 concentrations, and bioaccumulation factors were log-transformed and analyzed for normality

201 using the Lilliefors test (Lilliefors, 1967). Earthworm trace metal concentrations and

202 bioaccumulation values were compared across earthworm genera, metal sources, and

203 experimental design conditions, where applicable using generalized linear mixed-effect models

204 (GLMMs) in MATLAB.

For the GLMMs, earthworm metal concentrations and soil concentrations were log-

206 transformed, continuous variables (soil trace metal concentrations, \%SOM, and pH) were treated

207 as fixed effects and categorical (ecophysiological group, earthworm genera, duration of metal

208 uptake and source of trace metals) as random effects. The GLMM model consisted of Normal

209 Distribution and Maximum pseudo likelihood fit method. This GLMM configuration was 
210 selected based upon the paired data distribution, residual plots, and Akaike information criterion

211 (AIC) values. Results for the GLMM analyses are given in Table 2. Interactions among the

212 experimental design variables (ecophysiological group, earthworm genera, duration of metal

213 uptake and source of trace metals) were explored for log-transformed earthworm tissue

214 concentrations for metals with the most robust data sets $(\mathrm{Cd} \mathrm{n}=579, \mathrm{Cu} \mathrm{n}=608, \mathrm{~Pb} \mathrm{n}=593$, and

$215 \mathrm{Zn} \mathrm{n}=601)$. To test for data set biases in earthworm tissue concentrations among earthworm

216 genera, uptake duration groups, and ecophysiological groups, an N-Way ANOVA with post-hoc

217 t-tests were performed using MATLAB.

218

219

\section{Results and Discussion}

\subsubsection{Earthworm trace metal concentrations}

221

Our meta-analysis of 56 studies shows that earthworms are able to bioaccumulate

222 potentially hazardous concentrations of many toxic metals. Median earthworm tissue

223 concentrations of $\mathrm{Hg}, \mathrm{Pb}$, and $\mathrm{Cd}$ were above concentrations found to be hazardous for

224 consumption of rodents and fowlby the United States National Research Council (Table 1)

225 (NRC, 2006). Moreover, mean and median earthworm tissue concentrations show

226 bioaccumulation of $\mathrm{Zn}, \mathrm{Ni}$, and As near levels that may be hazardous to small mammals and

227 avian (Table 1). The extent to which earthworms bioaccumulate trace metals is influenced both

228 by the regulation of internal tissue concentrations by earthworms (Spurgeon and Hopkin 1999;

229 Karaca et al., 2010; Natal-da-Luz et al., 2011) and by the chemical bioavailability of the trace

230 metals in the soil they inhabit (Bradham et al 2006; Natal-da-Luz et al., 2011).

Most of the 56 studies included in our meta-analysis focused on contaminated soils. From

232 Table 1 however, we observe that median soil concentrations for $\mathrm{Hg}, \mathrm{Cd}, \mathrm{Cu}, \mathrm{Zn}, \mathrm{Mn}, \mathrm{Cr}, \mathrm{Ni}$, 
233 As, and $U$ are not greater than background concentrations (Table 1). Most median soil

234 concentrations fell within the range of typical soil concentrations for trace metals as reported by

235 Adriano (2001) and Kabata-Pendias and Mukherjee (2007). However, arithmetic mean and third

236 quartile (Q3) of soil concentrations were substantially elevated above background soil

237 concentrations for $\mathrm{Hg}, \mathrm{Pb}, \mathrm{Cd}, \mathrm{Cu}, \mathrm{Zn}$, and $\mathrm{Sb}$ (Table 1). Many of the trace metal concentrations

238 in samples were near background due to their role as a control soil in experiments that also

239 included contaminated soils, or where soil was collected from non-point source contaminated

240 sites. The elevated trace metal concentrations are from sites that have historical legacies of

241 smelting (e.g. Nannoni et al., 2001; Zhang et al., 2009), agricultural soils following application

242 of biosolids and sewage (e.g. Liu et al., 2005; Centofanti et al., 2016), or former mining

243 operations (e.g. Morgan and Morgan, 1990; Sizmur et al., 2011; Wang et al., 2018). Elevated

244 concentrations in soils were also observed in soils artificially amended in the laboratory using

245 metal salts (e.g. Dang et al., 2015). Mean $\mathrm{Hg}, \mathrm{Pb}, \mathrm{Sb}$, and U soil concentrations were skewed far

246 above the interquartile range (Table 1), indicating some experimental designs utilized

247 concentrations that far exceed values commonly found in the environment.

248 To explore the role of soil concentrations on earthworm trace metal uptake, we used

249 power also referred to as log-linear regressions, as opposed to linear regressions, to avoid bias

250 towards higher concentrations with larger numbers. Power regressions showed that the soil

251 concentrations strongly predict uptake of $\mathrm{Hg}$ and $\mathrm{Cd}$ in earthworm tissues $\left(p<0.01, R^{2}>0.35\right.$,

252 Supplemental Figure 1). Soil concentrations of the other metals, $\mathrm{Cu}, \mathrm{Cr}, \mathrm{Pb}, \mathrm{Zn}, \mathrm{Ni}, \mathrm{Mn}$, and $\mathrm{As}$,

253 as well as $\mathrm{Sb}$ and U not shown in Supplemental Figure 1, did not predict earthworm uptake,

254 explaining less than $20 \%$ of the variation in tissue concentrations $\left(R^{2}<0.20 ; p>0.05\right.$;

255 Supplemental Figure 1). These results agree with previous studies that found $\mathrm{Hg}$ and $\mathrm{Cd}$ soil 
256 concentrations drive uptake across several earthworm species (e.g. Richardson et al., 2015; Da

257 Silva et al., 2016; González-Alcaraz et al., 2018; Wang et al,. 2019). Moreover, the results agree

258 with previous studies that found soil concentrations did not drive $\mathrm{Cu}, \mathrm{Zn}$, or $\mathrm{Pb}$ earthworm tissue

259 concentrations (e.g. Nahmani et al., 2007; Wang et al., 2012; Richardson et al., 2015; González-

260 Alcaraz et al., 2018).

261 We further investigated the influence of soil concentrations on earthworm tissues

262 concentrations using generalized linear mixed effect models (GLMM). The model was structured

263 as $[$ Earthworm $]=1+$ Ecophysiological Group + Genera $+[$ Soil $]+$ Metal Source + Uptake

264 duration $+\mathrm{pH}+$ organic matter, where all variables were categorical except for soil

265 concentrations, $\mathrm{pH}$, and organic matter. GLMM results show that when source of metal, duration

266 of exposure to metals, and soil parameters are taken into account, soil concentrations were

267 significantly correlated with earthworm tissue concentrations for $\mathrm{Hg}, \mathrm{Cd}, \mathrm{Cu}, \mathrm{Zn}, \mathrm{As}, \mathrm{Sb}$, and $\mathrm{U}$

268 (Table 2, p < 0.05). From these results, we hypothesised that the contrasting findings of these

269 studies were due to differences in the earthworm species adopted and other differences in

270 experimental design across the 56 studies. These issues are further explored in the following

271 sections.

272

273 3.1.2 Earthworm trace metal concentrations across ecophysiological groups and genera

274 Earthworm tissue concentrations were significantly different between ecophysiological

275 groups for $\mathrm{Hg}, \mathrm{Pb}, \mathrm{Cd}, \mathrm{Zn}, \mathrm{Sb}$, and U using GLMM ( $\mathrm{p}<0.05)$ but not for $\mathrm{Cu}, \mathrm{Mn}$, and $\mathrm{Cr}$.

276 Epigeic earthworms had significantly higher $\mathrm{Hg}$, As, and Sb tissue concentrations than the other

277 ecophysiological groups (Figure 1). Epi-endogeic earthworms had similar concentrations as

278 endogeic earthworms for $\mathrm{Pb}, \mathrm{Cd}, \mathrm{Cu}, \mathrm{Zn}, \mathrm{Mn}, \mathrm{Cr}, \mathrm{Ni}, \mathrm{As}$, and $\mathrm{U}$ (Figure 1), but had significantly 
279 lower $\mathrm{Hg}$ concentrations than endogeic earthworms. These results suggest that no

280 ecophysiological group consistently achieves higher or lower trace metals concentrations.

281 Furthermore, the uptake of several metals were not influenced by ecophysiological group at all,

282 hinting that choice of food (i.e. mineral soil vs litter) or dermal contact does not affect their

283 uptake. Lastly, differences in trace metal tissue concentrations between ecophysiological groups

284 may be influenced by additional variables not considered such as variations between species

285 within a group.

Our GLMM analysis indicates that earthworm tissue concentrations varied among

earthworm genera for most metals ( $\mathrm{Hg}, \mathrm{Pb}, \mathrm{Cd}, \mathrm{Cu}, \mathrm{Zn}, \mathrm{Mn}, \mathrm{Sb}, \mathrm{U})$ (Table 2). When focusing on specific earthworm genera, our analysis only compared genera where $\mathrm{N}>10$ for at least five of the metals analyzed in this study. Thus, comparisons for Diplocardia, Drawidia, Pontoscolex, Octolaision and Sparganophilus were not included in this study due to small sample sizes. There

291 does not appear to be any genera most adept at bioaccumulating all metals, as differences among 292 genera were metal specific. For example; Eisenia had significantly higher As and $\mathrm{Hg}$ 293 concentrations than all other genera; Aporrectodea, Dendrodrilus, Eisenoides, and Lumbricus 294 had the highest Pb concentrations, and; Dendrodrilus had the highest Cd concentrations ( $\mathrm{p}<$ 295 0.05; Supplemental Table 3). Moreover, several of the trace metals (e.g. Cu, Zn, and U) for 296 which tissue concentrations were significantly affected by genera in the GLMM (Table 2) had 297 similar tissue concentrations across most genera $(\mathrm{p}>0.10$; Supplemental Table 3). There are 298 important within-genus differences to take into consideration. First, earthworms within the same 299 genus can have very different feeding and burrowing habits (e.g. anecic Lumbricus terrestris and 300 epi-endogeic Lumbricus rubellus). Second, earthworms within the same genera may inhabit 301 different soils affecting their exposure to trace metal concentrations. Lastly, physiological 
differences such as their length and surface area of folds within their intestines and excretion capabilities influence metal concentrations in their tissues (Morgan and Morgan, 1990; Morgan and Morgan, 1992; Spurgeon and Hopkins 1999).

\subsubsection{Earthworm bioaccumulation factors}

Our meta-analysis of 56 studies shows that earthworms consistently bioaccumulated $\mathrm{Hg}$, $\mathrm{Cd}$, and $\mathrm{Zn}$ on the basis of Q1 and Median BAFs > 1.0 (Table 1) and power regressions (Supplemental Figure 1). Earthworms were able to bioaccumulate $\mathrm{Pb}, \mathrm{Cu}, \mathrm{Cr}, \mathrm{Ni}, \mathrm{Sb}$, $\mathrm{As}$, and $\mathrm{U}$ only under certain circumstances, on the basis of Q3 BAFs > 1.0 (Table 1) and power regressions (Supplemental Figure 1). The limited bioaccumulation of $\mathrm{Pb}, \mathrm{Cu}, \mathrm{Cr}, \mathrm{Ni}, \mathrm{Sb}$, and $\mathrm{U}$, were likely driven by two specific conditions: highly elevated soil concentrations with reduced uptake tissue concentrations due to saturation and very low soil concentrations with low earthworm uptake causing BAFs to not exceed 1.0. When examining soil concentrations and BAFs in XY space in Supplemental Figure 2, it is clear that $\mathrm{As}, \mathrm{Cd}, \mathrm{Cr}, \mathrm{Cu}, \mathrm{Hg}, \mathrm{Mn}, \mathrm{Ni}$, and $\mathrm{Zn}$ have significantly higher BAF when soil concentrations are low ( $\mathrm{p}<0.05, \mathrm{R}^{2}$ ranged between 0.14 and 0.78 ). Lead BAF was not significantly affected by soil concentration $\left(\mathrm{p}>0.10, \mathrm{R}^{2}=0.00\right)$. One mechanism for decreasing BAFs with increasing soil concentration is mistaken scavenging as limiting essential elements (such as $\mathrm{Hg}$ for Se in Richardson et al., 2015) and increased regulation and excretion at elevated concentrations to maintain homeostasis (such as $\mathrm{Mn}$ for $\mathrm{Ca}$ in Morgan et al 2007).

We investigated the importance of earthworm type (ecophysiological group, genera) and soil properties (soil extraction methods, soil $\mathrm{pH}, \mathrm{SOM}$ ), accounting for differences in experimental design (source of metals, uptake duration) using generalized linear mixed-effect 
325 models (GLMMs). The GLMM for BAF was structured as [Earthworm] = $1+$ Ecophysiological

326 Group + Genera + Soil Extraction Method + Metal Source + Uptake duration + pH + organic

327 matter, where all variables were categorical except for $\mathrm{pH}$ and organic matter. Since soil

328 concentrations are used to calculated BAF, they cannot be added to the model. The BAF GLMM 329 results are given in Table 3 and described and interpreted in the following sections.

\subsubsection{Earthworm bioaccumulation factor across genera and ecophysiological groups}

GLMMs revealed that earthworm genera was a significant factor influencing BAF for all trace metals. Our BAFs in Supplemental Table 3 show some genera bioaccumulated metals at

334 higher rates than others but no specific genus consistently bioaccumulated the highest

335 concentration of all trace metals. For example, Lumbricidae genera (Allobophora, Aporrectodea, 336 Dendrobaena, and Dendrodrilus) all bioaccumulated $\mathrm{Pb}, \mathrm{Cd}, \mathrm{Cu}, \mathrm{Zn}$, and $\mathrm{Ni}$ at greater rates than 337 Megascoelidae genera Metaphire and Pheretima group (Supplemental Table 3, p < 0.05). Similar 338 to the GLMMs for earthworm tissue concentrations, our analysis only compared genera where $\mathrm{N}$ $339>10$ for at least five of the metals analyzed in this study, thus, Diplocardia, Drawidia, 340 Pontoscolex, Octolaision and Sparganophilus were not included. Moreover, comparisons

341 between genera are limited as earthworms within the same genus can have different feeding and 342 burrowing habits and may also be influenced by their preferred soil physiochemical properties. 343 In addition, there are physiological differences between earthworms to consider. For example, 344 the substantially reduced calciferous glands of Megascolecidae compared to earthworms of 345 Lumbricidae (both Aporrectodea and Lumbricus) may influence the assimilation and 346 bioaccumulation of trace metals. 
348 Endogeic earthworms had significantly higher BAFs for $\mathrm{Pb}, \mathrm{Cd}, \mathrm{Cr}, \mathrm{Sb}$ than all other groups

349 from GLMMs ( $<$ 0.05; Figure 1). Further, epigeic earthworms had significantly higher BAFs

350 for $\mathrm{Hg}, \mathrm{Cu}, \mathrm{Ni}$, and As than all other ecophysiological groups from GLMMs ( $<$ 0.05; Figure 1).

351 Lastly, anecic earthworms had the lowest BAFs for $\mathrm{Hg}, \mathrm{Pb}, \mathrm{Cd}, \mathrm{Ni}$, and $\mathrm{Sb}$ from GLMMs $(\mathrm{p}<$

352 0.05). BAFs can be high for epigeic earthworms due to high metal concentrations in the organic

353 rich soils they inhabit at high densities and endogeic earthworms can live in low organic matter

354 soil found in urban areas and point source polluted sites such as smelters (e.g. Morgan and

355 Morgan, 1990). Anecic earthworms consume fresh plant litter that typically have lower trace

356 metal concentrations than the partially decomposed organic matter consumed by epigeic and

357 endogeic earthworms (Bohlen et al., 2004; Karaca et al,.2010; Richardson et al., 2015).

358 Moreover, anecic earthworms can perform 'external' rumen digestive actions, in which they re-

359 ingest previously digested soils to consume fungal grazers and colonizing microbial communities

360 (Lavelle et al 1994). Epi-endogeic earthworms did not have BAFs resembling endogeic or

361 epigeic earthworms, highlighting their adaptive feeding behavior (Figure 1). Additional studies

362 are required to investigate comparability across metal concentrations, the earthworm diets, and

363 field versus laboratory conditions, all of which can influence trace metal bioaccumulation and

364 retention in their tissues.

365

\subsubsection{Experimental design - Source of metals}

The bioavailability of metals is strongly dependent on its phase in soil, as metals present

368 in native silicates or forged-alloyed metals by humans are generally unavailable for immediate uptake by earthworms while exchangeable or dissolved forms are readily available for uptake. 
370 Frequently studies focus on one type of metal source and have not compared how the source of a 371 metal affects the interpretation of uptake and bioaccumulation results. Using GLMMs, we found

372 that the source of metals significantly impacted earthworm tissue concentrations for $\mathrm{Hg}, \mathrm{Pb}, \mathrm{Cd}$,

$373 \mathrm{Cu}, \mathrm{Zn}, \mathrm{Cr}, \mathrm{Ni}$, and As (Table 3). We further examined this effect in Figure 2 to determine if

374 there were any trends among types of metal sources. Our results show that earthworms

375 inhabiting soils affected by mining activities, smelting, laboratory spiking, and non-point source

376 pollution (e.g. urban soils) had higher tissue concentrations of $\mathrm{Hg}, \mathrm{Cd}, \mathrm{Cu}, \mathrm{Cr}, \mathrm{Ni}$, and $\mathrm{As}$ than

377 earthworms exposed to background soil concentrations found in pristine environments (Figure

378 2). Further, we observed that earthworms in agricultural soils exhibited tissue concentrations

379 similar to, or below, the tissue concentrations of earthworms exposed to background soil

380 concentrations for $\mathrm{Pb}, \mathrm{Zn}$, and $\mathrm{Mn}$ (Figure 2). We therefore conclude that the source of metal

381 increased uptake of trace metals by earthworms rather than not simply elevated concentrations

382 pollution consistently results in.

GLMMs showed that the source of metal can significantly influence BAFs, which may be

384 the result of experimental design. Experiments using laboratory spiking methods, where a metal

385 salt is added to a soil, produced BAFs that were significantly higher than background BAFs for

$386 \mathrm{Hg}, \mathrm{Cu}, \mathrm{Ni}$, and As (Figure 2). However, this effect was not consistent since laboratory spiking

387 generated a very low $\mathrm{Pb} \mathrm{BAFs}$ and did not affect $\mathrm{Cd}, \mathrm{Zn}, \mathrm{Mn}$, and $\mathrm{Cr}$ BAFs, compared to

388 background BAFs (Figure 2). Mining and smelting activities did not produce significantly higher

$389 \mathrm{BAFs}$ for $\mathrm{Pb}, \mathrm{Cd}, \mathrm{Zn}, \mathrm{Mn}$, and $\mathrm{Ni}$ when compared to background BAFs but did generate

390 inconsistent positive and negative effects on BAFs for $\mathrm{As}, \mathrm{Cr}, \mathrm{Cu}, \mathrm{Hg}$, and $\mathrm{U}$ (Figure 2). We

391 hypothesise that soil properties and concentration of laboratory spiking method can generate

392 artefacts for testing bioaccumulation due to differences in complexation, sorption, and 
393 precipitation (Kumpiene et al 2008). The high solubility of trace metals applied by laboratory

394 spiking can result in higher dissolved concentrations in the soils to which the earthworms are

395 exposed (Nahmani et al., 2007), which may be unrealistic when compared to natural systems that

396 have had longer for the soil to 'age' and the dissolved concentration is allowed to come into

397 equilibrium with the adsorbed or precipitated phase.

398 Soil properties were important variables influencing BAFs for some metals. Da Silva et al 399 (2016) spiked low pH soils ( $\mathrm{pH} 4)$ with high concentrations of $\mathrm{Hg}$, creating a large bioavailable $400 \mathrm{Hg}$ pool and high BAFs while Wijayawardena et al., (2017) spiked high pH soils (pH $5-8.5$ ) 401 with $\mathrm{Pb}$, creating a large insoluble, unavailable $\mathrm{Pb}$ reservoir with low earthworm $\mathrm{BAFs}$ when 402 assessed for total soil $\mathrm{Pb}$. Soil concentrations in highly contaminated systems may be elevated to 403 the point that where BAFs are low even though tissue accumulation is high. One example is soil 404 near mining and smelting operations. In these systems, high concentrations in the soil drive high 405 accumulation in earthworm tissues but the BAF remains low because it is defined as the ratio of 406 tissue to soil concentrations. Non-point source pollution did not have significantly different 407 BAFs than background BAFs for most metals: $\mathrm{As}, \mathrm{Cd}, \mathrm{Cu}, \mathrm{Cr}, \mathrm{Hg}, \mathrm{Pb}, \mathrm{Mn}$, and $\mathrm{Ni}$, and $\mathrm{Zn}$, 408 (Figure 2). These results suggest that using a source of metal contamination that best mimics 409 natural systems can recreate natural bioaccumulation pathways of metal uptake while still 410 generating elevated earthworm tissue metal concentrations. Laboratory spiking of soils with trace 411 metals or using point source polluted sites from mining or smelting has the potential to generate 412 experimental artefacts when findings are applied to non-point source polluted sites (e.g. degraded 413 areas or urban areas) and limit broad applicability of results. 
The duration that earthworms are exposed to a soil can influence the bioaccumulation of

417 metals, as earthworm require time to attenuate to soil metal concentrations through soil ingestion

418 (see Spurgeon and Hopkin 1999) and passive diffusion across their skin (Vijver et al 2003). Our

$419 \mathrm{GLMM}$ analysis shows earthworm tissue concentrations for $\mathrm{Hg}, \mathrm{Pb}, \mathrm{Cd}, \mathrm{Cu}, \mathrm{Zn}$, and $\mathrm{As}$ were

420 significantly influenced by the duration of exposure to the soils (Table 2). Although one would

421 expect the longest duration to cause the greatest uptake of metals, this was not always the case.

422 Longer exposure durations to $\mathrm{Cd}$ and $\mathrm{Zn}$ produced the highest earthworm tissue concentrations

423 (Figure 3), but short and medium duration experiments generated the highest concentrations of

$424 \mathrm{Hg}$, As, and Sb (Figure 3).

425 Our GLMM analysis showed BAFs for $\mathrm{Hg}, \mathrm{Pb}, \mathrm{Cd}, \mathrm{Cu}, \mathrm{Zn}$, and As were significantly

426 influenced by the duration of exposure to the soils (Table 3). Short duration experiments $(<2$

427 weeks) generated the lowest $\mathrm{BAFs}$ for $\mathrm{Hg}, \mathrm{Pb}, \mathrm{Cd}, \mathrm{Cu}, \mathrm{Zn}$ and $\mathrm{Sb}$ compared to entire life

428 durations (Figure 3). Medium duration experiments (3 to 6 weeks) generated low BAFs for $\mathrm{Pb}$,

$429 \mathrm{Cd}$, and $\mathrm{Sb}$ and high $\mathrm{BAFs}$ for $\mathrm{Hg}, \mathrm{Cr}, \mathrm{Ni}$, and $\mathrm{As}$ compared to entire life durations (Figure 3).

430 Similarly, long duration experiments (6 to 20 weeks) were more closely aligned with entire life

431 studies for some metals $(\mathrm{Cd}, \mathrm{Cu}, \mathrm{Zn}, \mathrm{Mn})$ but also generated metals with significantly higher $(\mathrm{Cr}$,

$432 \mathrm{Ni}$ ) or lower ( $\mathrm{Pb}, \mathrm{As}) \mathrm{BAFs}$ compared to entire life studies (Figure 3).

433 These results highlight that duration of experiments can also limit interpretations from

434 laboratory-based experiments to field experiments. As with comparisons of earthworm tissues

435 among experiment durations, several factors regarding duration of exposure could be responsible

436 for the effect. First, short experiments can use concentrations that negatively impact their health

437 and alters physiology and behavior, or are lethal but their short duration allows for survival.

438 Second, earthworms may be unable to attenuate to a dynamic equilibrium of tissue trace metal 
concentrations (particularly for essential elements) within the experimental duration (Spurgeon and Hopkins 1999). Lastly, there may be covariance with the metal source as short duration experiments with high soil metal concentrations typically use soils spiked with metal salts which are highly bioavailable (Nahmani et al, 2007). Thus, experiment duration may be an important variable or covary with other variables and additional field-based studies are needed uptake and bioaccumulation under natural conditions.

\subsubsection{Experimental design - Extraction method impact on BAFs}

There are dozens of standardized extraction and digestion methods to assess trace metals in soils with varying purposes, ranging from assessing mobility, exchangeability, inorganic sorption, organic complexation, precipitation within secondary oxides, silicate forms, and total concentrations (Rao et al., 2008). The choice of extraction procedure may meet specific research aims for evaluating soil, but may affect comparability when calculating BAFs. Our GLMM found that soil extraction method significantly biased BAFs for most metals: $\mathrm{Pb}, \mathrm{Cd}, \mathrm{Cu}, \mathrm{Zn}, \mathrm{Cr}$, $\mathrm{Ni}$, and As (Table 3).

In Supplemental Figure 3, we compared BAFs calculated from five categories of extraction methods: water soluble being the least exhaustive, exchangeable focusing on cation exchangeable metals using a salt (e.g. $\mathrm{CaCl}_{2}$ or $\mathrm{MgCl}_{2}$ ), extractable using an organic ligand (e.g. EDTA or DTPA) or weak acid (dilute nitric acid or acetic acid), pseudototal digestion (e.g. concentrated $\mathrm{HNO}_{3}, \mathrm{HCl}, \mathrm{H}_{2} \mathrm{SO}_{4}$ or some combination), and total digestions ( $\mathrm{HF}, \mathrm{HClO}_{4}$, $\mathrm{H}_{3} \mathrm{PO}_{4}$ ). Our analysis shows that pseudototal and total digestions consistently produced BAFs that were similar for all metals (Supplemental Figure 3). Using exchangeable or extractable soil concentrations consistently generated higher BAFs than pseudototal or total digestion methods (Supplemental Figure 3). However, BAFs measured using water soluble phases produced BAFs 
462 similar to pseudototal or total digestion for some metals (e.g. $\mathrm{Cd}, \mathrm{Cu}, \mathrm{Ni}$ ) but also generated 463 significantly higher BAFs for other metals ( $\mathrm{Zn}$ and As).

The impact of the soil extraction method on BAFs has two important ramifications for 465 considering if metals are bioaccumulated and to what extent. First, using BAFs relies on the 466 assumption that $>1.0$ means metals are actively bioaccumulated by earthworm physiologically

467 but this analysis shows extraction method can affect these results. For example, $\mathrm{Cu}$ and Ni BAFs 468 measured with pseudototal and total digestions are <1.0, suggesting they are not actively 469 bioaccumulated. However, if exchangeable and extractable concentrations are used to calculate 470 BAFs for $\mathrm{Cu}$ and $\mathrm{Ni}$, then BAFs are $>1.0$ and they are considered actively bioaccumulated. We 471 recommend using BAFs for pseudototal and total digestions, as other extraction procedures may 472 overestimate BAFs through underestimating soil metal concentrations. Second, if other soil 473 extraction methods are desired, the assumption of 1.0 being an inflection point of

474 bioaccumulation may need to be reconsidered and a new point dependent on the soil extraction 475 method would be warranted. However, we argue that authors should avoid this later framework 476 for consistency in the literature.

$477 \quad$ 3.3.4 Interactions among experimental design and data set biases

478 Our N-Way ANOVA analysis found significant interactions among earthworm genera, 479 uptake duration, and ecophysiological groups for $\mathrm{Cd}, \mathrm{Cu}, \mathrm{Pb}$, and $\mathrm{Zn}$ (Supplemental Table 2). As 480 a prime example, litter-feeding and dwelling earthworms of the genus Eisenia fetida were 481 consistently used in shorter duration laboratory experiments than mineral soil dwelling, 482 earthworms genera conducted for their entire lifetimes under field conditions. This is simply due 483 to the fact that Eisenia fetida are a preferred model soil dwelling laboratory organism due to their 
484 short life cycle, maturation in $\sim 50$ days, ease of care on organic wastes, and ability to reproduce 485 and live in high densities (OECD 1984).

In spite of our efforts to include a diverse array of studies on bioaccumulation, it is

487 important to note key limitations and biases in our data set. First, trace metal data were primarily

$488 \mathrm{Cd}, \mathrm{Cu}, \mathrm{Pb}$ and $\mathrm{Zn}$ data ( $>$ > 500), while metals such as $\mathrm{Cr}, \mathrm{Hg}, \mathrm{Mn}, \mathrm{Ni}, \mathrm{Sb}$, U were reported less

489 often $(\mathrm{n}<200)$. Second, data from agricultural areas and non-point source polluted sites are

490 underreported ( $\mathrm{n}<0$ to 51$)$ compared to areas near mining and smelting activities $(\mathrm{n}=70$ to

491 150). Third, Lumbricidae were overrepresented (mean across trace metals $n=41 \%$ ) compared to

492 Megascolecidae (mean $n=10 \%$ ) and Glossoscolecidae (mean $n=6 \%$ ). Fourth, anecic

493 earthworms (mean across trace metals $n=10 \%$ ) were understudied compared to epigeic (mean $n$

$494=44 \%)$, endogeic (mean $n=23 \%)$, epi-endogeic (mean $n=23 \%$ ) earthworms. Lastly, our study

495 did not utilize the breadth of studies examining toxicokinetics, commonly due to additional

496 treatments affecting uptake and excretion rates. Thus, our study primarily utilized organisms that 497 spent their entire life cycle in the soil (mean across trace metals $n=73 \%$ ) as opposed to shorter 498 exposure durations.

499

500

\section{Conclusions}

The uptake and bioaccumulation of trace metals is important for ecotoxicological

502 research to ensure earthworm predators are not at risk of toxicity and an underappreciated aspect

503 of soil biogeochemistry. Our study demonstrated that specific metals, such as $\mathrm{Hg}, \mathrm{Cd}$, and $\mathrm{Zn}$ are 504 taken up and bioaccumulated across earthworm genera. Other metals, such as $\mathrm{Pb}, \mathrm{Cu}, \mathrm{Ni}, \mathrm{As}$, can 505 also be taken up and bioaccumulated under certain conditions. Traditionally, we consider the 506 primary driver of trace metals in earthworm tissues to be their respective soil concentrations. 
However, many other factors play a role in uptake, particularly for metals where earthworm and

508 soil concentrations were poorly correlated: $\mathrm{Pb}, \mathrm{Cu}, \mathrm{Zn}, \mathrm{Mn}, \mathrm{Cr}, \mathrm{Ni}, \mathrm{As}, \mathrm{Sb}$, and $\mathrm{U}$. These

509 additional factors can be environmental conditions, which include, but are not limited to, genus

510 of earthworm, ecophysiological group, soil $\mathrm{pH}$, and organic matter content. Moreover,

511 anthropogenic activities can also control the uptake and bioaccumulation of trace metals through

512 different trace metal sources (e.g. non-point source pollution, smelting, mining). Unfortunately,

513 the manner by which we study uptake and bioaccumulation of trace metals can generate artefacts

514 that limit generalizability of results from many studies. Experimental design limitations include

515 the spiking soils with substantially elevated concentrations of metals in the laboratory, reduction

516 of the duration of exposure before full effects may be realized, and underestimating total metal

517 concentrations with weak extraction procedures.

518

520 5. Research Needs

5215.1 Reporting full trace metal sets

522 Many studies only report values for a limited set of trace metals and determining co-

523 variance and element competition has remained largely unexplored. When possible, reporting

524 full sets of trace metals analyzed with appropriate QA/QC should be a standard. Measurement of

525 a consistent suite of metals aids researchers interested in other trace metals and also provides

526 insights into whether metals are co-varying or co-bioaccumulated by earthworms. We

527 recommend that researchers utilizing Atomic Absorption Spectroscopy, Inductively Coupled

528 Plasma Optical or Atomic Emission Spectrometry, and Inductively Coupled Plasma Mass

529 Spectrometry measure $\mathrm{As}, \mathrm{Cd}, \mathrm{Cu}, \mathrm{Pb}, \mathrm{Ni}$, and $\mathrm{Zn}$ as primary suite of common inorganic soil 
530 contaminants. A secondary suite consisting of $\mathrm{Co}, \mathrm{Cr}, \mathrm{Sb}, \mathrm{Sn}, \mathrm{U}$, and $\mathrm{W}$ are proposed as a suite

531 of emerging and site-specific pollutants that may be elevated in earthworms, but the literature

532 severely lacks data on these metals. The measurement of $\mathrm{Hg}$ should only be done with either a

533 direct mercury analyzer or an established ICP-MS protocol. Lastly, data should be published in

534 accessible formats. Tables with metal concentrations for each treatment, each site, or lowest

535 applicable treatment unit so data can be further interpreted. Cumulative figures and in-text

536 reporting are not recommended for promoting accessible data. With widely available

537 supplemental data submissions with publishers and data repositories, researchers must consider

538 making their data available for future studies to build upon.

\subsection{Exploring earthworms beyond E. fetida, L. terrestris, and L. rubellus}

The abundance of studies on L. terrestris and E. fetida are not a surprise as they have

542 been considered model organisms for laboratory study. In our study, E. fetida $(\mathrm{N}=141 / 951), L$.

543 terrestris $(\mathrm{N}=67 / 951)$, and L. rubellus $(\mathrm{N}=104 / 951)$ were the three most commonly studied

544 species of earthworms, constituting $33 \%$ of the earthworms studied. While this is advantageous

545 for reproducibility when studying molecular scale processes, physiological responses, and

546 genetic processes, it severely limits application to field studies where hundreds of species are

547 understudied. Moreover, the focus on E. fetida is problematic as it is a small, organic-rich soil

548 dependent earthworm, most commonly studied under laboratory conditions, and data focused on

549 this earthworm skew results towards their preferred type of soil environment. Our GLMM results

550 show that $\mathrm{pH}$ and organic matter can significantly impact earthworm tissue concentrations and

551 bioaccumulation of trace metals. Thus, additional studies on uptake and bioaccumulation of

552 endogeic and epi-endogeic earthworms are needed and should consider being conducted at the 
553 earthworm community-level. Moreover, further studies on Asiatic and American earthworms of

554 the families Megascolecidae, Acanthodrilidae, Moniligastridae, and Glossoscolecidae are

555 required to further our understanding.

556

$557 \quad 5.3$ Earthworm field studies at larger scales

$558 \quad$ Most field studies have focused on limited point-source polluted sites. However, this 559 causes a lack of field scale studies investigating soils at the ecosystem level and their influence 560 on earthworm uptake and bioaccumulation of trace metals. More regional to continental scale 561 studies are needed to accurately capture the influence of soil properties (e.g. pH, SOM, texture, 562 structure) and environmental parameters (e.g. soil moisture, temperature) on metal uptake and 563 bioaccumulation. In addition, changes to metal cycling in the environment can influence many 564 other properties important at the global scale (e.g. organo-metalloid disruption releasing DOC, 565 leaching of nutrients decreasing plant growth).

566

$567 \quad 5.4$ Earthworms in agricultural settings

568 Another effect of focusing on laboratory soils with amended trace metal concentrations, 569 is a lack of data on background metal concentrations across earthworm genera. Field and 570 laboratory studies are needed to determine background, natural, or uncontaminated concentration 571 data for earthworms. Due to the limited background data, it is difficult to assess if earthworms 572 are exhibiting contaminated or polluted trace metal concentrations or if these are differences due 573 to their physiology.

574

575 
577 This work was supported by a grant from the College of Natural Sciences at the University of

578 Massachusetts Amherst to Dr. Justin Richardson. The authors are thankful for helpful comments

579 from the five anonymous reviewers.

580

581

582

583

584

585

586

587

588

589

590

591

592

593

594

595

596

597

598

599

600

601

602

603

604

605

606

607

608

609

610

611

612

613

614

615

616

617

\section{References}

Adriano, D.C., 2001. Trace elements in terrestrial environments, biogeochemistry, Bioavailability, and Risks of Metals. 2nd Ed. Springer ISBN 0-387-98678-2

Alvarenga, P., Laneiro, C., Palma, P., de Varennes, A. and Cunha-Queda, C., 2013. A study on $\mathrm{As}, \mathrm{Cu}, \mathrm{Pb}$ and $\mathrm{Zn}$ (bio) availability in an abandoned mine area (Sao Domingos, Portugal) using chemical and ecotoxicological tools. Environmental Science and Pollution Research, 20(9), pp.6539-6550.

Álvarez, C.R., Moreno, M.J., Bernardo, F.G., Martín-Doimeadios, R.R. and Nevado, J.B., 2014. Mercury methylation, uptake and bioaccumulation by the earthworm Lumbricus terrestris (Oligochaeta). Applied soil ecology, 84, pp.45-53.

Alves, P.R.L., da Silva, E.B., Cardoso, E.J.B.N. and Alleoni, L.R.F., 2018. Ecotoxicological impact of arsenic on earthworms and collembolans as affected by attributes of a highly weathered tropical soil. Environmental Science and Pollution Research, 25(14), pp.13217-13225.

Andre, J., Stürzenbaum, S.R., Kille, P., Morgan, A.J. and Hodson, M.E., 2010. Metal bioaccumulation and cellular fractionation in an epigeic earthworm (Lumbricus rubellus): the interactive influences of population exposure histories, site-specific geochemistry and mitochondrial genotype. Soil biology and Biochemistry, 42(9), pp.1566-1573.

Aziz, A.A., Lee, B.T., Han, H.J. and Kim, K.W., 2019. Assessment of the stabilization of heavy metal contaminants in soils using chemical leaching and an earthworm bioassay. Environmental geochemistry and health, 41(1), pp.447-460.

Bengtsson, G., Nordström, S. and Rundgren, S., 1983. Population density and tissue metal concentration of lumbricids in forest soils near a brass mill. Environmental Pollution Series A, Ecological and Biological, 30(2), pp.87-108.

Beyer, W.N., Cromartie, E.J., 1987. A Survey of Pb, Cu, Zn, Cd, Cr, As, and Se in earthworms and soil from diverse Sites. Environmental Monitoring and Assessment 8,27-36.

Beyer, W.N., Codling, E.E. and Rutzke, M.A., 2018a. Anomalous bioaccumulation of lead in the earthworm Eisenoides lonnbergi (Michaelsen). Environmental toxicology and chemistry, 37(3), pp.914-919. 
Beyer, W.N., Casteel, S.W., Friedrichs, K.R., Gramlich, E., Houseright, R.A., Nichols, J.R., Karouna-Renier, N.K., Kim, D.Y., Rangen, K.L., Rattner, B.A. and Schultz, S.L., 2018b. Biomarker responses of Peromyscus leucopus exposed to lead and cadmium in the Southeast Missouri Lead Mining District. Environmental monitoring and assessment, 190(2), p.104.

Blouin, M., Sery, N., Cluzeau, D., Brun, J.J. and Bédécarrats, A., 2013. Balkanized research in ecological engineering revealed by a bibliometric analysis of earthworms and ecosystem services. Environmental management, 52(2), pp.309-320.

Bohlen, P.J., Scheu, S., Hale, C.M., McLean, M.A., Migge, S., Groffman, P.B., Parkinson, D., 2004. Non-native invasive earthworms as agents of change in northern temperate forests. Frontiers of Ecology and Environment 8,427-435.

Bradham KD, Dayton EA, Basta NT, Schroder J, Payton M, Lanno RP. 2006. Effect of soil properties on lead bioavailability and toxicity to earthworms. Environ Toxicol Chem 25:769775.

Buch, A.C., Brown, G.G., Correia, M.E.F., Lourençato, L.F. and Silva-Filho, E.V., 2017. Ecotoxicology of mercury in tropical forest soils: impact on earthworms. Science of the Total Environment, 589, pp.222-231.

Bull, K.R., Roberts, R.D., Inskip, M.J. and Goodman, G.T., 1977. Mercury concentrations in soil, grass, earthworms and small mammals near an industrial emission source. Environmental Pollution (1970), 12(2), pp.135-140.

Burton, D.T., Turley, S.D., Fisher, D.J., Green, D.J. and Shedd, T.R., 2006. Bioaccumulation of total mercury and monomethylmercury in the earthworm Eisenia fetida. Water, Air, and Soil Pollution, 170(1-4), pp.37-54.

Centofanti, T., Chaney, R.L., Beyer, W.N., McConnell, L.L., Davis, A.P. and Jackson, D., 2016. Assessment of trace element accumulation by earthworms in an orchard soil remediation study using soil amendments. Water, Air, \& Soil Pollution, 227(9), p.350.

Coelho, C., Foret, C., Bazin, C., Leduc, L., Hammada, M., Inácio, M. and Bedell, J.P., 2018. Bioavailability and bioaccumulation of heavy metals of several soils and sediments (from industrialized urban areas) for Eisenia fetida. Science of the Total Environment, 635, pp.13171330 .

Cotter-Howells, J., Charnock, J.M., Winters, C., Kille, P., Fry, J.C. and Morgan, A.J., 2005. Metal compartmentation and speciation in a soil sentinel: the earthworm, Dendrodrilus rubidus. Environmental science \& technology, 39(19), pp.7731-7740.

Da Silva, E., Nahmani, J., Lapied, E., Alphonse, V., Garnier-Zarli, E. and Bousserrhine, N., 2016. Toxicity of mercury to the earthworm Pontoscolex corethrurus in a tropical soil of French Guiana. Applied soil ecology, 104, pp.79-84. 
Dai, J., Becquer, T., Rouiller J.H., Reversat, G., Berhard-Reversat, F., Nahmani, J., Lavelle, P., 2004. Heavy metal accumulation by two earthworm species and its relationship to total and

Dang, F., Zhao, J., Greenfield, B.K., Zhong, H., Wang, Y., Yang, Z. and Zhou, D., 2015. Soil geochemistry and digestive solubilization control mercury bioaccumulation in the earthworm Pheretima guillemi. Journal of hazardous materials, 292, pp.44-51.

Dang, F., Zhao, J. and Zhou, D., 2016. Uptake dynamics of inorganic mercury and methylmercury by the earthworm Pheretima guillemi. Chemosphere, 144, pp.2121-2126.

Du, Y.L., He, M.M., Xu, M., Yan, Z.G., Zhou, Y.Y., Guo, G.L., Nie, J., Wang, L.Q., Hou, H. and Li, F.S., 2014. Interactive effects between earthworms and maize plants on the accumulation and toxicity of soil cadmium. Soil Biology and Biochemistry, 72, pp.193-202.

Duarte, A.P., Brown, G.G. and Pauletti, V., 2014. Earthworm (Pontoscolex corethrurus) survival and impacts on properties of soils from a lead mining site in Southern Brazil. Biology and fertility of soils, 50(5), pp.851-860.

Elyamine, A., Moussa, M., Ismael, M., Wei, J., Zhao, Y., Wu, Y. and Hu, C., 2018. Earthworms, rice straw, and plant interactions change the organic connections in soil and promote the decontamination of cadmium in soil. International journal of environmental research and public health, 15(11), p.2398.

Filzek, P.D.B., Spurgeon, D.J., Broll, G., Svendsen, C., Hankard, P.K., Kammenga, J.E., Donker, M.H., Weeks, J.M., 2004. Pedological Characterisation of Sites Along a Transect from a Primary Cadmium/Lead/Zinc Smelting Works. Ecotoxicology 13, 725-737.

Fischer E, Molnar L (1993) Environmental aspects of the chlorogogenous tissue of earthworms. Soil Biol Biochem 24:1723-1727.

Fraser, A., Lambkin, D.C., Lee, M.R., Schofield, P.F., Mosselmans, J.F.W. and Hodson, M.E., 2011. Incorporation of lead into calcium carbonate granules secreted by earthworms living in lead contaminated soils. Geochimica et Cosmochimica Acta, 75(9), pp.2544-2556.

Frelich, L.E., Hale, C.M., Scheu, S., Holdsworth, A.R., Heneghan, L., Bohlen, P.J., Reich, P.B., 2006. Earthworm invasion into previously earthworm-free temperate and boreal forests. Biological Invasions 8,1235-1245. DOI 10.1007/s10530-006-9019-3

Gomez-Eyles, J.L., Sizmur, T., Collins, C.D. and Hodson, M.E., 2011. Effects of biochar and the earthworm Eisenia fetida on the bioavailability of polycyclic aromatic hydrocarbons and potentially toxic elements. Environmental Pollution, 159(2), pp.616-622. 
González-Alcaraz, M.N., Loureiro, S. and van Gestel, C.A., 2018. Toxicokinetics of Zn and Cd in the earthworm Eisenia andrei exposed to metal-contaminated soils under different combinations of air temperature and soil moisture content. Chemosphere, 197, pp.26-32.

Görres, J.H., Melnichuk, R.D.S., 2012. Asian invasive earthworms of the genus Amynthas kinberg in Vermont. Northeastern Naturalist 19,313-322.

Han, F.X., Su, Y., Shi, Z., Xia, Y., Tian, W., Philips, V., Monts, D.L., Gu, M. and Liang, Y., 2012. Mercury distribution and speciation in floodplain soils and uptake into native earthworms (Diplocardia spp.). Geoderma, 170, pp.261-268.

Hobbelen, P.H.F., Koolhaas, J.E., van Gestel, C.A.M., 2006a. Bioaccumulation of heavy metals in the earthworms Lumbricus rubellus and Aprorrectodea caliginosa in relation to total and available metal concentrations in field soils. Environmental Pollution 144, 639 - 646.

Hobbelen, P.H.F., Van den Brink, P.J., Hobbelen, J.F. and Van Gestel, C.A.M., 2006b. Effects of heavy metals on the structure and functioning of detritivore communities in a contaminated floodplain area. Soil Biology and Biochemistry, 38(7), pp.1596-1607.

Hooda, P. (Ed.). (2010). Trace elements in soils. John Wiley \& Sons.

Ireland, M.P., 1979. Metal accumulation by the earthworms Lumbricus rubellus, Dendrobaena veneta and Eiseniella tetraedra living in heavy metal polluted sites. Environmental Pollution 19,201-206.

Ireland, M.P., 1983. Heavy metal uptake and tissue distribution in earthworms. In Earthworm ecology. E.d. JE Satchell. Springer Netherlands, 1983, 247-265.

Jelaska, L.Š., Jurasović, J., Brown, D.S., Vaughan, I.P. and Symondson, W.O., 2014. Molecular field analysis of trophic relationships in soil-dwelling invertebrates to identify mercury, lead and cadmium transmission through forest ecosystems. Molecular ecology, 23(15), pp.3755-3766.

Karaca, A., Kizilkaya, R., Turgay, O.C. and Cetin, S.C., 2010. Effects of earthworms on the availability and removal of heavy metals in soil. In Soil Heavy Metals (pp. 369-388). Springer, Berlin, Heidelberg.

Kennette, D., Hendershot, W., Tomlin, A. and Sauvé, S., 2002. Uptake of trace metals by the earthworm Lumbricus terrestris L. in urban contaminated soils. Applied soil ecology, 19(2), pp.191-198.

Kizilkaya, R., 2004. Cu and Zn accumulation in earthworm Lumbricus terrestris L. in sewage sludge amended soil and fractions of $\mathrm{Cu}$ and $\mathrm{Zn}$ in casts and surrounding soil. Ecological Engineering, 22(2), pp.141-151.

Kumpiene, J., Lagerkvist, A. and Maurice, C., 2008. Stabilization of As, Cr, Cu, Pb and Zn in soil using amendments-a review. Waste management, 28:215-225. 
Latif, R., Malek, M., Mirmonsef, H., 2013. Cadmium and lead accumulation in three endogeic earthworm species. Bulletin of Environmental Contamination and Toxicology 90,456-459.

Lavelle, P., 1979. Relations entre types ecologiques et profils demographiques chez les vers de terre de la savanne de Lamto (Cote d'Ivoire). Revue D Ecologie et de Biologie du sol, 16,85101.

Lavelle, P., Gilot, C., Fragoso, C. and Pashanasi, B., 1994. Soil fauna and sustainable land use in the humid tropics.

Lemtiri, A., Liénard, A., Alabi, T., Brostaux, Y., Cluzeau, D., Francis, F. and Colinet, G., 2016. Earthworms Eisenia fetida affect the uptake of heavy metals by plants Vicia faba and Zea mays in metal-contaminated soils. Applied soil ecology, 104, pp.67-78.

Leveque, T., Capowiez, Y., Schreck, E., Mazzia, C., Auffan, M., Foucault, Y., Austruy, A. and Dumat, C., 2013. Assessing ecotoxicity and uptake of metals and metalloids in relation to two different earthworm species (Eiseina hortensis and Lumbricus terrestris). Environmental pollution, 179 , pp.232-241.

Li, L., Xu, Z., Wu, J. and Tian, G., 2010. Bioaccumulation of heavy metals in the earthworm Eisenia fetida in relation to bioavailable metal concentrations in pig manure. Bioresource technology, 101(10), pp.3430-3436.

Lilliefors, H. 1967. On the Kolmogorov-Smirnov test for normality with mean and variance unknown. Journal of American Statistical Association, 62,399-402.

Lukkari T., Teno S., Väisänen, A., Haimi, J., 2006. Effects of earthworms on decomposition and metal availability in contaminated soil: Microcosm studies of populations with different exposure histories. Soil Biology and Biochemistry 38, $359-370$.

Ma, W., Edelman, T., van Beersum, I., Jans, T., 1983. Uptake of cadmium, zinc, lead, and copper by earthworms near a zinc-smelting complex: influence of soil $\mathrm{pH}$ and organic matter. Bulletin of Environmental Contamination and Toxicology. 30,424-427.

Ma, W.C., 1987. Heavy metal accumulation in the mole, Talpa europea, and earthworms as an indicator of metal bioavailability in terrestrial environments. Bulletin of Environmental Contamination and Toxicology, 39(6), pp.933-938.

Maleri, R.A., Reinecke, A.J. and Reinecke, S.A., 2008. Metal uptake of two ecophysiologically different earthworms (Eisenia fetida and Aporrectodea caliginosa) exposed to ultramafic soils. Applied soil ecology, 38(1), pp.42-50.

Mombo, S., Laplanche, C., Besson, P., Sammartino, S., Schreck, E., Dumat, C. and Capowiez, Y., 2018. Metal soil pollution differentially affects both the behaviour and exposure of A. caliginosa and L. terrestris: a mesocosm study. Biology and fertility of soils, 54(3), pp.319-328. 
Morgan, A., Morris, B., 1982. The accumulation and intracellular compartmentation of cadmium, lead, zinc and calcium in two earthworm species (Dendrobaena rubida and Lumbricus rubellus) living in highly contaminated soil. Histochemistry 75, 269-285.

Morgan, J.E., Morgan, A.J., 1990. The distribution of cadmium, copper, lead, zinc and calcium in the tissues of the earthworm Lumbricus rubellus sampled from one uncontaminated and four polluted soils. Oecologia 84,559-566.

Morgan, J.E. and Morgan, A.J., 1992. Heavy metal concentrations in the tissues, ingesta and faeces of ecophysiologically different earthworm species. Soil Biology and Biochemistry, 24(12), pp.1691-1697.

Morgan, J.E., Morgan, A.J., 1999. The accumulation of metals ( $\mathrm{Cd}, \mathrm{Cu}, \mathrm{Pb}, \mathrm{Zn}$ and $\mathrm{Ca}$ ) by two ecologically contrasting earthworm species (Lumbricus rubellus and Aporrectodea caliginiosa): implications for ecotoxicological testing. Applied Soil Ecology 13,9-20.

Morgan, A.J., Pleasance, B., Kinsey, H., Murphy, D. and Davies, S., 2007. The manganese relationships of ecophysiologically contrasting earthworm species (Lumbricus rubellus and Aporrectodea caliginosa) inhabiting manganese-mine soils. European Journal of Soil Biology, 43, pp.S297-S302.

Nahmani, J., Hodson, M.E., Black, S., 2007. A review of studies performed to assess metal uptake by earthworms. Environmental pollution 145, 402-424.

Nannoni, F., Protano, G. and Riccobono, F., 2011. Uptake and bioaccumulation of heavy elements by two earthworm species from a smelter contaminated area in northern Kosovo. Soil biology and biochemistry, 43(12), pp.2359-2367.

Nannoni, F., Rossi, S. and Protano, G., 2014. Soil properties and metal accumulation by earthworms in the Siena urban area (Italy). Applied soil ecology, 77, pp.9-17.

Natal-da-Luz, T., Ojeda, G., Costa, M., Pratas, J., Lanno, R.P., Van Gestel, C.A.M. and Sousa, J.P., 2011. Short-term changes of metal availability in soil. II: The influence of earthworm activity. Applied soil ecology, 49, pp.178-186.

(NRC) National Research Council, 2006. Mineral tolerance of animals: 2005. National Academies Press.

Neuhauser, E.F., Cukic, Z.V., Malecki, M.R., Loehr, R.C., Durkin, P.R. 1995. Bioconcentration and biokinetics of heavy metals in the earthworm. Environmental Pollution 89,293 - 301 .

OECD (1984). Guidelines for the testing of chemicals No. 207 Earthworm acute toxicity tests. OECD Adopted 4 April 1984. 
Oliveira Resende, A.P., Santos, V.S.V., Campos, C.F., Morais, C.R.D., de Campos Júnior, E.O., Oliveira, A.M.M.D. and Pereira, B.B., 2018. Ecotoxicological risk assessment of contaminated soil from a complex of ceramic industries using earthworm Eisenia fetida. Journal of Toxicology and Environmental Health, Part A, 81(20), pp.1058-1065.

Pagotto, C., Remy, N., Legret, M. and Le Cloirec, P., 2001. Heavy metal pollution of road dust and roadside soil near a major rural highway. Environmental Technology, 22(3), pp.307-319.

Peng, B., Song, Z., Tu, X., Xiao, M., Wu, F. and Lv, H., 2004. Release of heavy metals during weathering of the Lower Cambrian black shales in western Hunan, China. Environmental Geology, 45(8), pp.1137-1147.

Pérès, G., Vandenbulcke, F., Guernion, M., Hedde, M., Beguiristain, T., Douay, F., Houot, S., Piron, D., Richard, A., Bispo, A. and Grand, C., 2011. Earthworm indicators as tools for soil monitoring, characterization and risk assessment. An example from the national Bioindicator programme (France). Pedobiologia, 54, pp.S77-S87.

Popic, J.M., Salbu, B. and Skipperud, L., 2012. Ecological transfer of radionuclides and metals to free-living earthworm species in natural habitats rich in NORM. Science of the total environment, 414, pp.167-176.

Piearce, T.G., 1972. The calcium relations of selected Lumbricidae. Journal of Animal Ecology 41,167-188.

Rao, C.R.M., Sahuquillo, A. and Sanchez, J.L., 2008. A review of the different methods applied in environmental geochemistry for single and sequential extraction of trace elements in soils and related materials. Water, Air, and Soil Pollution, 189(1-4), pp.291-333.

Renoux, A.Y., Rocheleau, S., Sarrazin, M., Sunahara, G.I. and Blais, J.F., 2007. Assessment of a sewage sludge treatment on cadmium, copper and zinc bioavailability in barley, ryegrass and earthworms. Environmental Pollution, 145(1), pp.41-50.

Richardson, J.B., 2019. Trace Elements in Surface Soils and Megascolecidae Earthworms in Urban Forests Within Four Land-Uses Around Poughkeepsie, New York, USA. Bulletin of environmental contamination and toxicology, pp.1-6.

Richardson, J.B., Görres, J.H., Jackson, B.P. and Friedland, A.J., 2015. Trace metals and metalloids in forest soils and exotic earthworms in northern New England, USA. Soil Biology and Biochemistry, 85, pp.190-198.

Richardson, J.B., Renock, D.J., Görres, J.H., Jackson, B.P., Webb, S.M. and Friedland, A.J., 2016. Nutrient and pollutant metals within earthworm residues are immobilized in soil during decomposition. Soil Biology and Biochemistry, 101, pp.217-225. 
Rieder, S.R., Brunner, I., Horvat, M., Jacobs, A., Frey, B., 2011. Accumulation of mercury and methylmercury by mushrooms and earthworms from forest soils. Environmental Pollution 159,2861-2869.

Romero-Freire, A., Peinado, F.M., Ortiz, M.D. and Van Gestel, C.A.M., 2015. Influence of soil properties on the bioaccumulation and effects of arsenic in the earthworm Eisenia andrei. Environmental Science and Pollution Research, 22(19), pp.15016-15028.

Ruiz, E., Rodríguez, L. and Alonso-Azcárate, J., 2009. Effects of earthworms on metal uptake of heavy metals from polluted mine soils by different crop plants. Chemosphere, 75(8), pp.10351041.

Sample, B.E., Suter, G.W., Beauchamp, J.J. and Efroymson, R.A., 1999. Literature-derived bioaccumulation models for earthworms: Development and validation. Environmental Toxicology and Chemistry: An International Journal, 18(9), pp.2110-2120.

Scheu, S., 1987. Microbial activity and nutrient dynamics in earthworm casts (Lumbricidae). Biology and Fertility of Soils 5, 230-234.

Sheppard, S.C., Evenden, W.G., Cornwell, T.C., 1997. Depuration and uptake kinetics of I, Cs, $\mathrm{Mn}, \mathrm{Zn}$ and $\mathrm{Cd}$ by the earthworm (Lumbricus terrestris) in radiotracer-spiked litter. Environ. Toxicol. Chem. 16, $2106 \mathrm{e} 2112$.

Sizmur, T., Hodson M.E., 2009. Do earthworms impact metal mobility and availability in soil? A review. Environmental Pollution 157,1981 - 1989.

Sizmur, T., Tilston, E.L., Charnock, J., Palumbo-Roe, B., Watts, M.J., Hodson, M.E., 2011. Impacts of epigeic, anecic and endogeic earthworms on metal and metalloid mobility and availability. Journal of Environmental Monitoring 13, 266-273.

Smith, D.B., Cannon, W.F., Woodruff, L.G., Solano, Federico, and Ellefsen, K.J., 2014, Geochemical and mineralogical maps for soils of the conterminous United States: U.S. Geological Survey Open-File Report 2014-1082, 386 p., https://dx.doi.org/10.3133/ofr20141082.

Spurgeon DJ, Hopkin SP (1999) Comparisons of metal accumulation and excretion kinetics in earthworms (Eisenia fetida) exposed to contaminated field and laboratory soils. Appl Soil Ecol $11: 227-243$

Suthar, S., 2008. Metal remediation from partially composted distillery sludge using composting earthworm Eisenia fetida. Journal of Environmental Monitoring, 10(9), pp.1099-1106.

Suthar, S. and Singh, S., 2009. Bioconcentrations of metals (Fe, Cu, Zn, Pb) in earthworms (Eisenia fetida), inoculated in municipal sewage sludge: do earthworms pose a possible risk of terrestrial food chain contamination? Environmental Toxicology: An International Journal, 24(1), pp.25-32. 
Talmage, S.S. and Walton, B.T., 1993. Food chain transfer and potential renal toxicity of mercury to small mammals at a contaminated terrestrial field site. Ecotoxicology, 2(4), pp.243256.

Tijani, M.N., Okunlola, O.A. and Abimbola, A.F., 2006. Lithogenic concentrations of trace metals in soils and saprolites over crystalline basement rocks: a case study from SW Nigeria. Journal of African Earth Sciences, 46(5), pp.427-438.

Tosza, E., Dumnicka, E., Niklińska, M. and Rożen, A., 2010. Enchytraeid and earthworm communities along a pollution gradient near Olkusz (southern Poland). European Journal of Soil Biology, 46(3-4), pp.218-224.

Van Groenigen, J.W., Lubbers, I.M., Vos, H.M., Brown, G.G., De Deyn, G.B. and Van Groenigen, K.J., 2014. Earthworms increase plant production: a meta-analysis. Scientific reports, 4, p.6365.

Van Groenigen, J.W., Van Groenigen, K.J., Koopmans, G.F., Stokkermans, L., Vos, H.M. and Lubbers, I.M., 2019. How fertile are earthworm casts? A meta-analysis. Geoderma, 338, pp.525535.

Vijver, M.G., Vink, J.P., Miermans, C.J. and van Gestel, C.A., 2003. Oral sealing using glue: a new method to distinguish between intestinal and dermal uptake of metals in earthworms. Soil Biology and Biochemistry, 35(1), pp.125-132.

Wang, Q., Zhou, D., Cang, L., Li, L. and Zhu, H., 2009. Indication of soil heavy metal pollution with earthworms and soil microbial biomass carbon in the vicinity of an abandoned copper mine in Eastern Nanjing, China. European Journal of Soil Biology, 45(3), pp.229-234.

Wang, X., Chu, Z., Yao, J., Ji, M., Liu, G. and Dong, Z., 2012. A survey of Zn, Pb, Cd, Cr and $\mathrm{Cu}$ in earthworms and soil from subsidence area of Xieyi coal mine in Huainan, China. Asian Journal of Chemistry, 24(9), pp.4241-4242.

Wang, K., Qiao, Y., Zhang, H., Yue, S., Li, H., Ji, X. and Liu, L., 2018. Bioaccumulation of heavy metals in earthworms from field contaminated soil in a subtropical area of China. Ecotoxicology and environmental safety, 148, pp.876-883.

Wijayawardena, M.A., Megharaj, M. and Naidu, R., 2017. Bioaccumulation and toxicity of lead, influenced by edaphic factors: using earthworms to study the effect of $\mathrm{Pb}$ on ecological health. Journal of soils and sediments, 17(4), pp.1064-1072.

Zhang, Z.S., Zheng, D.M., Wang, Q.C. and Lv, X.G., 2009. Bioaccumulation of total and methyl mercury in three earthworm species (Drawida sp., Allolobophora sp., and Limnodrilus sp.). Bulletin of environmental contamination and toxicology, 83(6), p.937. 
Table 1 Soil and earthworm trace metal concentrations and calculated bioaccumulation factors across all 56 studies.

\begin{tabular}{|c|c|c|c|c|c|c|c|c|c|c|c|c|}
\hline & & As & $\mathrm{Cd}$ & $\mathrm{Cr}$ & $\mathrm{Cu}$ & $\mathrm{Hg}$ & $\mathrm{Mn}$ & $\mathrm{Ni}$ & $\mathrm{Pb}$ & $\mathrm{Sb}$ & $U$ & $\mathrm{Zn}$ \\
\hline & & $\mathrm{mg} \mathrm{kg}^{-1}$ & $\mathrm{mg} \mathrm{kg}^{-1}$ & $\mathrm{mg} \mathrm{kg}^{-1}$ & $\mathrm{mg} \mathrm{kg}^{-1}$ & $\mathrm{mg} \mathrm{kg}^{-1}$ & $\mathrm{mg} \mathrm{kg}^{-1}$ & $\mathrm{mg} \mathrm{kg}^{-1}$ & $\mathrm{mg} \mathrm{kg}^{-1}$ & $\mathrm{mg} \mathrm{kg}^{-1}$ & $\mathrm{mg} \mathrm{kg}^{-1}$ & $\mathrm{mg} \mathrm{kg}^{-1}$ \\
\hline \multirow[t]{4}{*}{$\begin{array}{l}\text { Soil } \\
\text { concentrations }\end{array}$} & Q1 & 1 & 0.3 & 10 & 14 & 0.06 & 389 & 5 & 14 & 0.1 & 0.11 & 53 \\
\hline & Median & 3 & 1.7 & 19 & 25 & 0.09 & 912 & 9 & 63 & 3.1 & 0.27 & 129 \\
\hline & Mean & 78 & 12.4 & 132 & 117 & 24.76 & 811 & 170 & 613 & 23.8 & 0.91 & 512 \\
\hline & Q3 & 22 & 5.8 & 57 & 77 & 0.39 & 1214 & 19 & 236 & 9.0 & 0.53 & 384 \\
\hline $\begin{array}{l}\text { Background soil } \\
\text { concentrations } \dagger\end{array}$ & & $0.1-55$ & $0.01-2$ & $10-150$ & $4-70$ & $0.03-0.2$ & $2-5000$ & $5-200$ & $5-40$ & $0.1-2.2$ & $0.1-102$ & $10-300$ \\
\hline \multirow[t]{4}{*}{$\begin{array}{l}\text { Earthworm tissue } \\
\text { concentrations }\end{array}$} & Q1 & 2 & 4 & 4 & 11 & 0.2 & 63 & 2 & 10 & 0.20 & 0.16 & 139 \\
\hline & Median & 4 & 15 & 11 & 18 & 0.6 & 153 & 5 & 32 & 0.39 & 0.31 & 330 \\
\hline & Mean & 53 & 44 & 22 & 34 & 44.7 & 202 & 12 & 181 & 4.25 & 0.42 & 545 \\
\hline & Q3 & 14 & 52 & 27 & 39 & 1.7 & 291 & 12 & 109 & 1.17 & 0.57 & 660 \\
\hline \multirow[t]{2}{*}{$\begin{array}{l}\text { Concentrations } \\
\text { hazardous to } \\
\text { rodents and fowl } \neq\end{array}$} & & 30 & 10 & 100 & 250 & 0.2 & 2000 & 50 & 10 & - & 100 & 500 \\
\hline & & $\begin{array}{l}\mathrm{mg} \mathrm{kg}^{-1} \\
/ \mathrm{mg} \mathrm{kg}^{-1}\end{array}$ & $\begin{array}{l}\mathrm{mg} \mathrm{kg}^{-1} \\
/ \mathrm{mg} \mathrm{kg}^{-}\end{array}$ & $\begin{array}{l}\mathrm{mg} \mathrm{kg}^{-1} \\
/ \mathrm{mg} \mathrm{kg}^{-}\end{array}$ & $\begin{array}{l}\mathrm{mg} \mathrm{kg}^{-1} \\
/ \mathrm{mg} \mathrm{kg}^{-}\end{array}$ & $\begin{array}{l}\mathrm{mg} \mathrm{kg}^{-1} \\
/ \mathrm{mg} \mathrm{kg}^{-1}\end{array}$ & $\begin{array}{l}\mathrm{mg} \mathrm{kg}^{-1} \\
/ \mathrm{mg} \mathrm{kg}^{-}\end{array}$ & $\begin{array}{l}\mathrm{mg} \mathrm{kg}^{-1} \\
/ \mathrm{mg} \mathrm{kg}^{-}\end{array}$ & $\begin{array}{l}\mathrm{mg} \mathrm{kg}^{-1} \\
/ \mathrm{mg} \mathrm{kg}^{-}\end{array}$ & $\begin{array}{l}\mathrm{mg} \mathrm{kg}^{-1} \\
/ \mathrm{mg} \mathrm{kg}^{-}\end{array}$ & $\begin{array}{l}\mathrm{mg} \mathrm{kg}^{-1} \\
/ \mathrm{mg} \mathrm{kg}^{-1}\end{array}$ & $\begin{array}{l}\mathrm{mg} \mathrm{kg}^{-1} \\
/ \mathrm{mg} \mathrm{kg}^{-}\end{array}$ \\
\hline
\end{tabular}




\begin{tabular}{|c|c|c|c|c|c|c|c|c|c|c|c|c|c|}
\hline \multirow{3}{*}{\multicolumn{2}{|c|}{$\begin{array}{l}\text { Bioaccumulatior } \\
\text { factor }\end{array}$}} & ion & 0.20 & 4.22 & 0.11 & 0.30 & 1.50 & 0.11 & 0.24 & 0.11 & 0.06 & 0.56 & 0.96 \\
\hline & & Median & 1.11 & 9.49 & 0.31 & 0.67 & 3.44 & 0.25 & 0.50 & 0.40 & 0.14 & 1.25 & 2.09 \\
\hline & & Mean & 140.4 & 25.4 & 67.3 & 12.1 & 13.4 & 0.64 & 2.40 & 6.36 & 21.24 & 1.48 & 9.83 \\
\hline Metal & $\mathrm{N}$ & $\begin{array}{c}\text { Ecophysio@aical } \\
\text { Group }\end{array}$ & \multicolumn{2}{|c|}{$\begin{array}{c}\text { 5.17 EarthwBinnß } \\
\text { Genera }\end{array}$} & $\begin{array}{l}1.41 \mathrm{~S} \\
\text { concer }\end{array}$ & $\begin{array}{l}1.45 \\
\text { tion }\end{array}$ & $\begin{array}{l}\text { Met\$7 } \\
\text { Source }\end{array}$ & $\begin{array}{l}\text { OL5ptake } \\
\text { duration }\end{array}$ & \multicolumn{3}{|c|}{${ }^{1.25}$ Soil $\mathrm{pH}^{1.55 \text { Soil ofgentic }}$ matter } & \multicolumn{2}{|c|}{ Model AIC 6.02} \\
\hline \multicolumn{2}{|c|}{$\begin{array}{l}\text { As } \quad 329 \\
\text { Observations }\end{array}$} & n.s. $\mathrm{N}$ & 33 & 1579 & $(+)<$ & 608 & $<0.01_{199}$ & $\begin{array}{c}(+)<0.01 \\
142\end{array}$ & & 593 & $(+)<0.01$ & $\begin{array}{l}33 \\
11\end{array}$ & \multirow[t]{2}{*}{601} \\
\hline $\mathrm{Cd}$ & 580 & $<0.01$ & & 01 & $(+)<$ & & $<0.01$ & $(+)<0.01$ & & s. & $(-)<0.01$ & 37 & \\
\hline
\end{tabular}

$\dagger \mathrm{Ba}$
$\mathrm{ckg}$
rou
nd
soil
concentrations are from reported values from Adriano (2001), Smith et al., (2014) and Kabata-pendias and Mukherjee (2007). $\ddagger$ Concentrations from Mineral Tolerance of Animals: 2005 by the United States National Research Council, NRC(2006).

Table 2 Model output p-values from generalize linear mixed effect models for earthworm trace metal tissue concentrations across 56 aggregated studies for random and fixed variables. (+) indicates a positive effect and (-) indicates a negative effect of a variable.

Akaike information criterion (AIC) values for selecting each model are also given. 


\begin{tabular}{cccccccccc}
$\mathrm{Cr}$ & 96 & n.s. & $<0.01$ & n.s. & $<0.01$ & n.s. & $(+)<0.01$ & n.s. \\
$\mathrm{Cu}$ & 608 & n.s. & $<0.01$ & $(+)<0.01$ & $<0.01$ & $(+)<0.01$ & n.s. & $(-)<0.01$ & 295 \\
$\mathrm{Hg}$ & 200 & $<0.01$ & $<0.01$ & $(+)<0.01$ & $<0.01$ & $(+)<0.01$ & n.s. & $(-)<0.01$ & 175 \\
$\mathrm{Mn}$ & 143 & n.s. & $<0.01$ & n.s. & n.s. & n.s. & $(+)<0.01$ & n.s. & 102 \\
$\mathrm{Ni}$ & 165 & n.s. & $<0.01$ & n.s. & $<0.01$ & n.s. & $(+)<0.01$ & n.s. & 117 \\
$\mathrm{~Pb}$ & 593 & $<0.01$ & $<0.01$ & n.s. & $<0.01$ & $(+)<0.01$ & n.s. & $(+)<0.01$ & 988 \\
$\mathrm{Sb}$ & 90 & $<0.01$ & $<0.01$ & $(+)<0.01$ & n.s. & n.s. & n.s. & n.s. & 48 \\
$\mathrm{U}$ & 112 & $<0.01$ & $<0.01$ & $(+)<0.01$ & n.s. & n.s. & $(-)<0.01$ & n.s. & 49 \\
$\mathrm{Zn}$ & 601 & $<0.01$ & $<0.01$ & $(+)<0.01$ & $<0.01$ & $(+)<0.01$ & n.s. & n.s. & 317 \\
\hline
\end{tabular}


Table 3 Model output p-values from generalize linear mixed effect models for earthworm BAF values across the 56 aggregated studies for random and fixed variables. (+) indicates a positive effect and (-) indicates a negative effect of a variable. Akaike information criterion (AIC) values for selecting each model are also given.

\begin{tabular}{cccccccc}
\hline Metal & $\mathrm{N}$ & $\begin{array}{c}\text { Ecophysiological } \\
\text { Group }\end{array}$ & $\begin{array}{c}\text { Earthworm } \\
\text { Genera }\end{array}$ & $\begin{array}{c}\text { Soil Extraction } \\
\text { Method }\end{array}$ & Metal & Source & Uptake \\
& & duration & Soil pH & $\begin{array}{c}\text { Soil organic } \\
\text { matter }\end{array}$ & Model AIC \\
& & & &
\end{tabular}




\begin{tabular}{cccccccccc} 
As & 329 & n.s. & $<0.01$ & $<0.01$ & $<0.01$ & $(+)<0.01$ & n.s. & n.s. & 487 \\
$\mathrm{Cd}$ & 580 & $<0.01$ & $<0.01$ & $<0.01$ & $<0.01$ & $(+)<0.01$ & $(-)<0.01$ & $(-)<0.01$ & 488 \\
$\mathrm{Cr}$ & 96 & n.s. & $<0.01$ & $<0.01$ & n.s. & n.s. & n.s. & n.s. & 95 \\
$\mathrm{Cu}$ & 608 & $<0.01$ & $<0.01$ & $<0.01$ & $<0.01$ & $(+)<0.01$ & n.s. & $(-)<0.01$ & 680 \\
$\mathrm{Hg}$ & 200 & $<0.01$ & $<0.01$ & n.s. & $<0.01$ & $(+)<0.01$ & n.s. & n.s. & 230 \\
$\mathrm{Mn}$ & 143 & n.s. & $<0.01$ & n.s. & n.s. & n.s. & $(+)<0.01$ & n.s. & 129 \\
$\mathrm{Ni}$ & 165 & n.s. & $<0.01$ & $<0.01$ & n.s. & n.s. & n.s. & n.s. & 137 \\
$\mathrm{~Pb}$ & 593 & $<0.01$ & $<0.01$ & $<0.01$ & $<0.01$ & $(+)<0.01$ & n.s. & n.s. & 1077 \\
$\mathrm{Sb}$ & 90 & $<0.01$ & $<0.01$ & n.s. & n.s. & n.s. & n.s. & n.s. & 76 \\
$\mathrm{U}$ & 112 & $<0.01$ & $<0.01$ & n.s. & n.s. & n.s. & $(-)<0.01$ & n.s. \\
$\mathrm{Zn}$ & 601 & $<0.01$ & $<0.01$ & $<0.01$ & $<0.01$ & $(+)<0.01$ & n.s. & $(-)<0.01$ & 79 \\
\hline
\end{tabular}



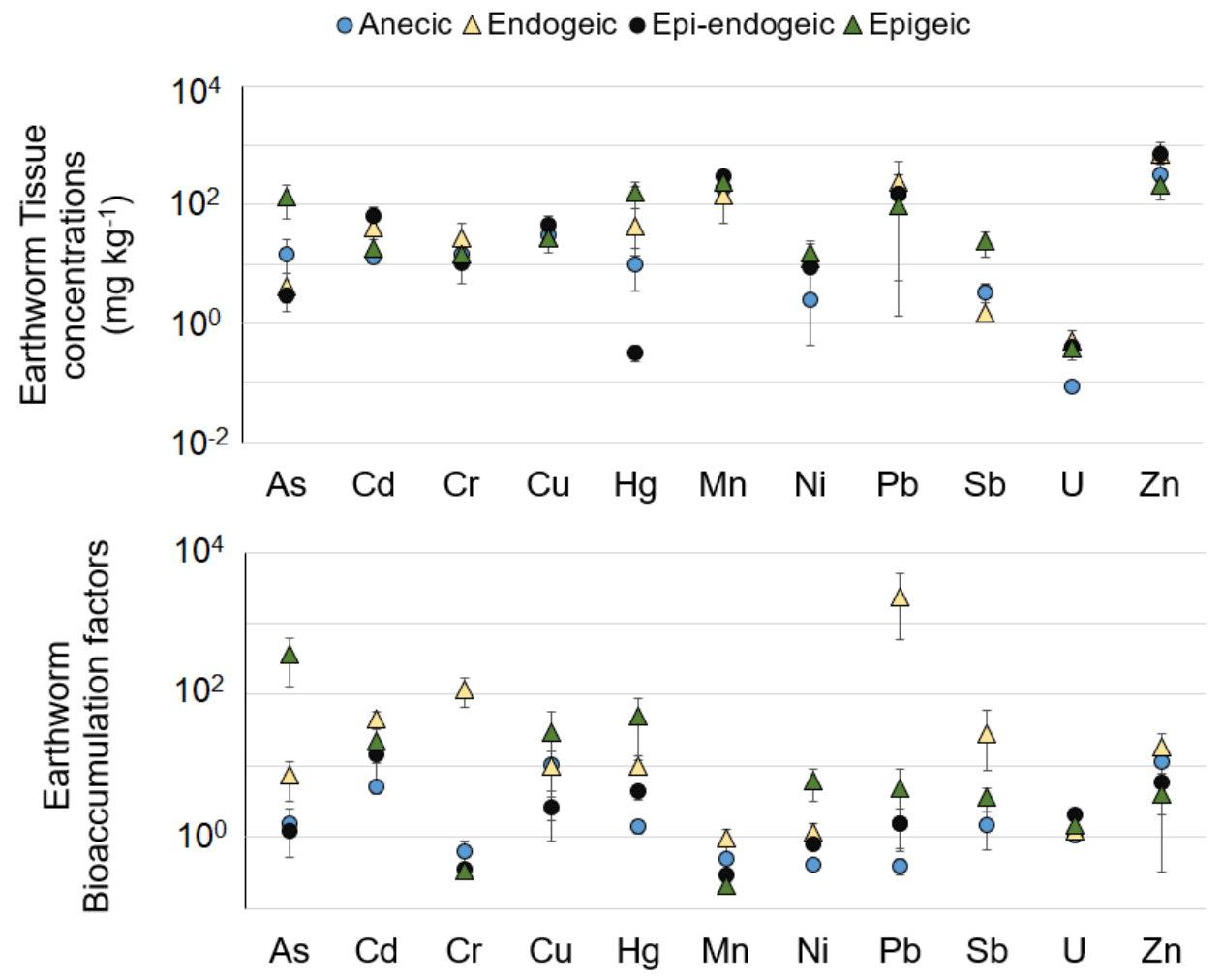

Figure 1 Earthworm trace metal concentrations and bioaccumulation factors (tissue concentrations divided by soil concentrations) across the 57 studies. Error bars are \pm 1 standard deviation. $\mathrm{N}$ for each plot is given in the supplemental materials. 

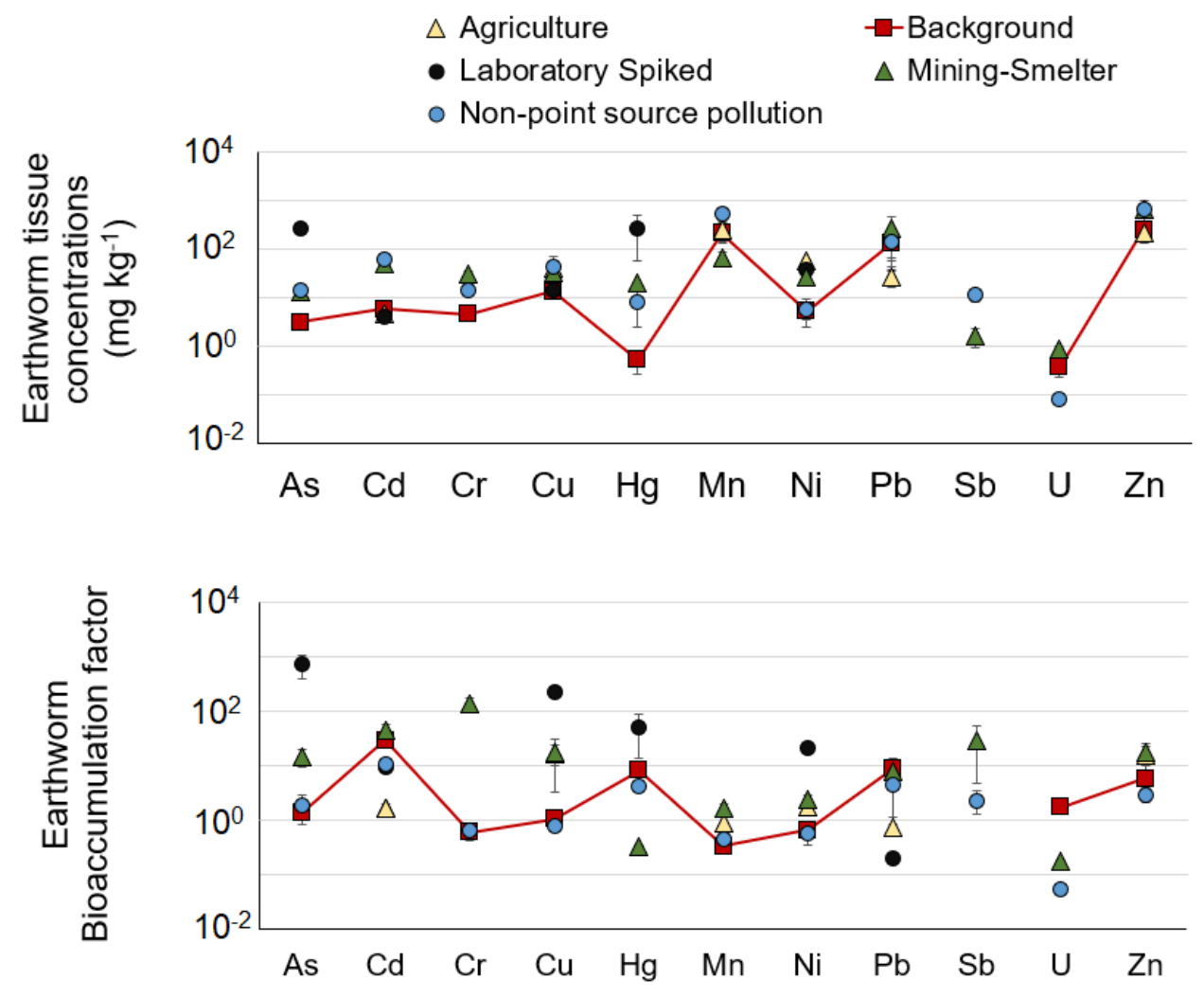

Figure 2 Plots of average earthworm tissue concentrations and bioaccumulation factors examined across types of metal sources for 56 studies. Error bars are \pm 1 standard deviation. $\mathrm{N}$ for each plot is given in the supplemental materials. 

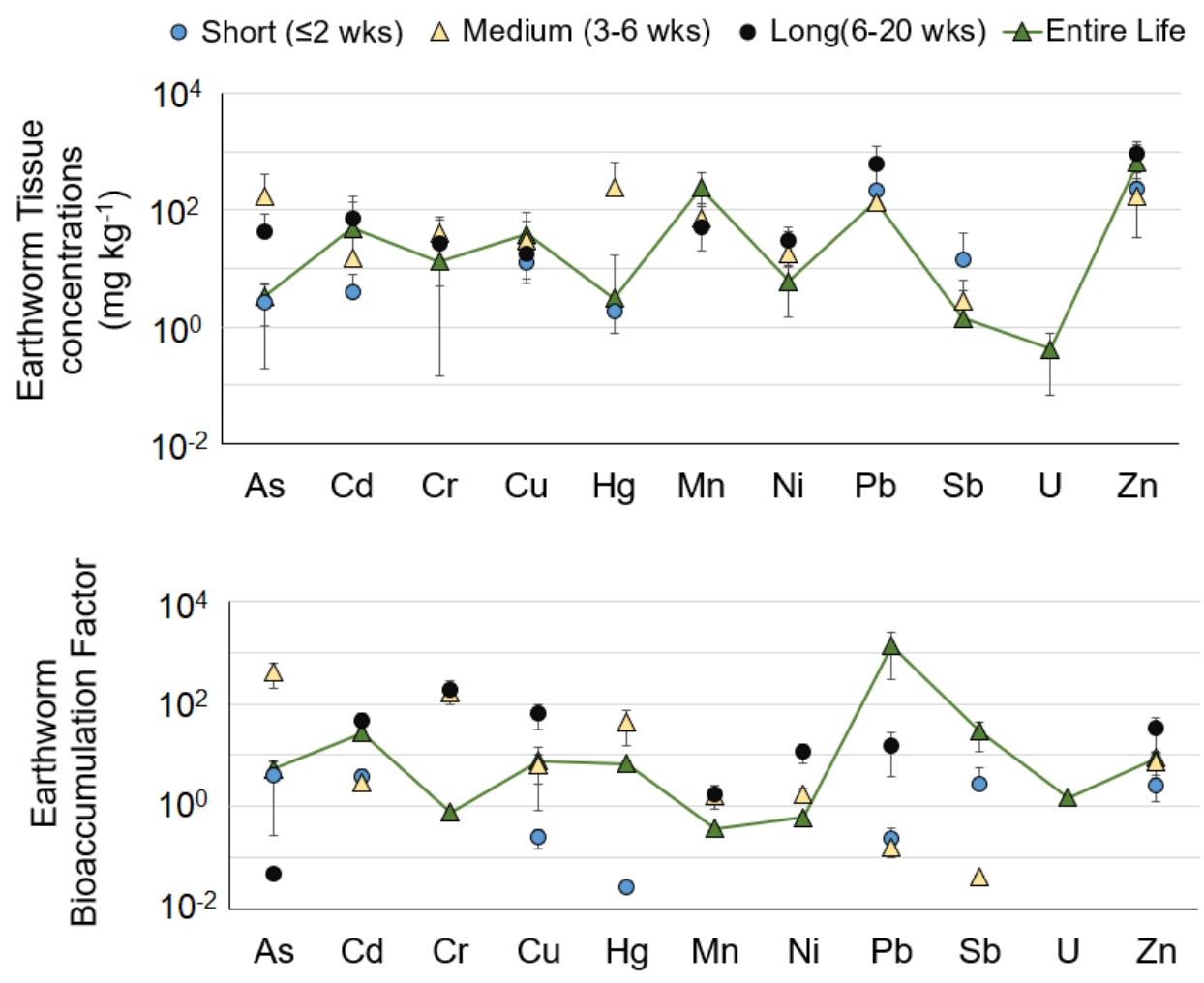

4 Figure 3 Earthworm trace metal concentrations and bioaccumulation factors (tissue

5 concentrations divided by soil concentrations) examined by duration of metal exposure across

6 the 56 studies. Error bars are \pm 1 standard deviation. $\mathrm{N}$ for each plot is given in the supplemental 7 materials. 